\title{
Article
}

\section{Evolutionary history and identification of conservation units in the giant otter, Pteronura brasiliensis.}

Pickles, RSA, Groombridge, J, Zambrana Rojas, VD, Van Damme, P, Gottelli, D, Kundu, S, Bodmer, R, Ariani, CV, lyengar, A and Jordan, WC

Available at http://clok.uclan.ac.uk/3828/

Pickles, RSA, Groombridge, Jl, Zambrana Rojas, VD, Van Damme, P, Gottelli, D, Kundu, S, Bodmer, R, Ariani, CV, lyengar, A et al (2011) Evolutionary history and identification of conservation units in the giant otter, Pteronura brasiliensis. Molecular Phylogenetics and Evolution, 61 (3). pp. 616-627. ISSN 1055-7903

It is advisable to refer to the publisher's version if you intend to cite from the work. http://dx.doi.org/10.1016/j.ympev.2011.08.017

For more information about UCLan's research in this area go to

http://www.uclan.ac.uk/researchgroups/ and search for <name of research Group>.

For information about Research generally at UCLan please go to http://www.uclan.ac.uk/research/

All outputs in CLoK are protected by Intellectual Property Rights law, including Copyright law. Copyright, IPR and Moral Rights for the works on this site are retained by the individual authors and/or other copyright owners. Terms and conditions for use of this material are defined in the policies page. 


\section{Accepted Manuscript}

Evolutionary history and identification of conservation units in the giant otter, Pteronura brasiliensis

R.S.A. Pickles, J.J. Groombridge, V.D. Zambrana Rojas, P. Van Damme, D. Gottelli, S. Kundu, R. Bodmer, C.V. Ariani, A. Iyengar, W.C. Jordan

PII: S1055-7903(11)00362-9

DOI: 10.1016/j.ympev.2011.08.017

Reference: YMPEV 4018

To appear in:

Molecular Phylogenetics and Evolution

Received Date:

30 July 2010

Revised Date:

1 August 2011

Accepted Date:

17 August 2011

Please cite this article as: Pickles, R.S.A., Groombridge, J.J., Zambrana Rojas, V.D., Van Damme, P., Gottelli, D., Kundu, S., Bodmer, R., Ariani, C.V., Iyengar, A., Jordan, W.C., Evolutionary history and identification of conservation units in the giant otter, Pteronura brasiliensis, Molecular Phylogenetics and Evolution (2011), doi: 10.1016/j.ympev.2011.08.017

This is a PDF file of an unedited manuscript that has been accepted for publication. As a service to our customers we are providing this early version of the manuscript. The manuscript will undergo copyediting, typesetting, and review of the resulting proof before it is published in its final form. Please note that during the production process errors may be discovered which could affect the content, and all legal disclaimers that apply to the journal pertain. 
1 Evolutionary history and identification of conservation

2 units in the giant otter, Pteronura brasiliensis

4 R. S. A. PICKLES, ab J. J. GROOMBRIDGE,b V. D. ZAMBRANA ROJAS, C P. VAN

5 DAMME, c D. GOTTELLI, a S. KUNDU,b R. BODMER,b C. V. ARIANI, a IYENGAR

6 A,e W. C. JORDAN a

8 a Institute of Zoology, Zoological Society of London, Regent's Park, London,

$9 \quad N W 14 R Y$

10 b Durrell Institute of Conservation and Ecology, Marlowe Building, University

11 of Kent, Canterbury, Kent, CT2 7NR

12 c Asociacíon FaunAgua, 5263 Cochabamba, Bolivia

13 d University of Cambridge, Downing Street, Cambridge, CB2 3EH

14 e University of Central Lancashire, Preston, PR $12 \mathrm{HE}$

16 Keywords: Pteronura, phylogeography, mitochondrial DNA, Amazonia,

17 refugia, paleodrainage, conservation units.

19 Corresponding author: Rob Pickles, Institute of Zoology, Zoological Society

20 of London, Regent's Park, London NW1 4RY. Tel: +44 (0) 2074496681 . Fax:

$21+44 \quad$ (0) $7586 \quad 2870 . \quad$ Email: $\quad$ robert.pickles@ioz.ac.uk;

$22 \quad$ rsapickles@hotmail.co.uk 
1

2 Running title: Phylogeography of Pteronura 


\section{Abstract}

2 The giant otter, Pteronura brasiliensis, occupies a range including the

3 major drainage basins of South America, yet the degree of structure that

4 exists within and among populations inhabiting these drainages is

5 unknown. We sequenced portions of the mitochondrial DNA (mtDNA)

6 cytochrome b (612 bp) and control region (383 bp) genes in order to

7 determine patterns of genetic variation within the species. We found high

8 levels of mtDNA haplotype diversity ( $h=0.93$ overall) and support for

9 subdivision into four distinct groups of populations, representing important

10 centers of genetic diversity and useful units for prioritizing conservation

11 within the giant otter. We tested these results against the predictions of

12 three hypotheses of Amazonian diversification (Pleistocene Refugia,

13 Paleogeography, and Hydrogeology). While the phylogeographic pattern

14 conformed to the predictions of the Refugia Hypothesis, molecular dating

15 using a relaxed clock revealed the phylogroups diverged from one

16 another between 1.69 and $0.84 \mathrm{Ma}$, ruling out the influence of Late

17 Pleistocene glacial refugia. However, the role of Plio-Pleistocene climate

18 change could not be rejected. While the molecular dating also makes

19 the influence of geological arches according to the Paleogeography

20 Hypothesis extremely unlikely, the recent Pliocene formation of the

21 Fitzcarrald Arch and its effect of subsequently altering drainage pattern

22 could not be rejected. The data presented here support the interactions 
1 of both climatic and hydrological changes resulting from geological

2 activity in the Plio-Pleistocene, in shaping the phylogeographic structure

3 of the giant otter.

4

5

\section{$6 \quad 1$. Introduction}

7 The giant otter, Pteronura brasiliensis, is distributed throughout north and

8 central South America, occurring in the drainage basins of the Amazon

9 (including the Tocantins), Orinoco and Parana'-Paraguay as well as the

10 Caribbean-draining Guianan river systems (Essequibo, Corentyne,

11 Marowijne and Oyapock) and the eastern Brazilian São Francisco Basin

12 (Fig. 1). The species is currently listed as Endangered in the IUCN Red List

13 following population collapse as a result of over-hunting for its pelt in the

14 last century (Duplaix et al. 2008). Although the threat of commercial

15 hunting has declined, habitat degradation has increased. The

16 environmental impact from mega-projects such as the canalization of the

17 River Paraguay, the construction of hydroelectric dams throughout

18 Amazonia and the transposition of the River São Francisco, combined with

19 widespread gold mining and increasing river traffic, cast into doubt the

20 recovery of the giant otter (Gottgens et al. 2001; Groenendijk et al. 2005;

21 Duplaix et al. 2008). Due to these continuing pressures, there is an urgent

22 need to determine the level of genetic diversity that exists within the 
1 species and how this is distributed across the range. Understanding the

2 geographic distribution of genetic variation within a species enables the

3 pinpointing of regions of high conservation importance, such as

4 populations which display a history of reproductive isolation from one

5 another and within which there may exist local adaptations (Moritz 2002).

6 Such an understanding is fundamental for targeting conservation efforts

7 to successfully manage the recovery of endangered species such as the

8 giant otter (Avise 2000).

10 Previous taxonomic divisions have recognized two subspecies, Pteronura

11 brasiliensis brasiliensis occurring throughout Amazonia, the Orinoco and

12 Guianas, and P. b. paranensis restricted to the Pantanal and the rivers

13 Paraná and Paraguay of the southerly flowing Parana'-Paraguay

14 drainage basin (Rengger 1830). The Pantanal subspecies was considered

15 to have a broader skull and larger teeth (Harris 1968). However, the

16 validity of this subdivision has been questioned due to the abnormal

17 dentition of the type specimen (Carter and Rosas 1997). Garcia et al.

18 (2007) used partial mitochondrial control region, cytochrome b and

19 cytochrome c oxidase I sequence data to investigate genetic variation

20 among giant otter populations in the central Amazon, parts of the River

21 Negro, Tapajos and Pantanal. This study found some evidence of

22 phylogeographic structure between the Amazon and Parana-Paraguay 
1 basins, but found an absence of structure within the central Amazon,

2 paving the way for the more extensive study we present here.

4 The giant otter is supported as being sister to the remaining Lutrinae, and

5 the two lineages are considered to have last shared a common ancestor

6 in the Miocene (Koepfli et al. 2008). Fossil evidence of Satherium

7 piscinarium, often considered a putative ancestor of the giant otter, has

8 been found in strata dated to the Pliocene (4.7 Ma) in North America

9 (Bjork 1973; Lindsay et al. 1984). However, resolving the exact relationship

10 of Satherium to Pteronura and the timing of the entry of the giant otter's

11 ancestor into South America and subsequent divergence of populations

12 has been confounded by a lack of fossil evidence. While Neotropical

13 otter (Lontra longicaudis) fossils dating to 0.98-1.8 Ma have been found in

14 Argentine deposits (Berman 1994 cited in Prevosti and Ferrero 2008), very

15 few giant otter fossils have been found in South America, the oldest of

16 which dates to the Pleistocene, 130,000-120,000 years before present (BP)

17 (Prevosti and Ferrero 2008). It is feasible that its ancestor may have crossed

18 to South America before the Great American Faunal Interchange (GAFI)

19 date of $3.5 \mathrm{Ma}$, as waif dispersal across the seaway had been occurring

20 for several million years beforehand (Flynn et al. 2005). Raccoons, for

21 example, are thought to have invaded mainland South America up to 7 
1 Ma, before complete closure of the isthmus (Fulton and Strobeck 2007;

2 Koepfli et al. 2007; Coates et al. 2004).

4 South America, and Amazonia specifically, holds some of the greatest

5 species diversity on the planet (Chazdon and Whitmore 2002), and over

6 the last 40 years our understanding of the ecological changes occurring

7 within the continent and their impact on species diversification has greatly

8 improved. Nevertheless, there has been a lack of investigation into the

9 reason for phylogeographic patterns within species (Tchaika et al. 2007).

10 This study adds to our understanding of Amazonian processes and

11 important regions of genetic diversity by focusing on the semi-aquatic

12 giant otter, investigating the impact of three hypotheses as explanations

13 for shaping the phylogeography of the species. These relate to

14 geological, hydrological, and climatic change experienced by South

15 America over the course of the Pliocene and Pleistocene. While giant

16 otters are semi-aquatic and thus not confined to water bodies to the

17 same extent as fish, often travelling overland to reach isolated ponds,

18 they are among the most aquatically adapted of all lutrines and are not

19 thought to travel large distances overland. Therefore, we have tested only

20 those hypotheses that may be equally applicable to both aquatic and

21 terrestrial taxa. 
1 The Paleogeography Hypothesis considers that patterns of geological

2 uplift in the Andes foreland basin may have led to populations becoming

3 separated and diverging through vicariance (Haffer 1997). In particular,

4 the rising of geological arches in Western Amazonia is considered to have

5 altered flow regimes, splitting lineages on either side of the arches,

6 resulting in vicariant divergence (Da Silva and Patton 1998; Hubert and

7 Renno 2006). This hypothesis has been challenged by Rossetti et al. (2003)

8 and Wesselingh and Salo (2006). These authors suggest that these

9 structures are predominantly extremely ancient (Palaeozoic and

10 Mesozoic) and buried under subsequent sedimentary deposits to the

11 extent that they barely cause elevations and could not be responsible for

12 the phylogeographic pattern seen in the majority of taxa. However,

13 Roddaz et al. (2006), Espurt et al. (2007), Regard et al. (2009) and Roddaz

14 et al. (2010) have shown that in Western Amazonia the Fitzcarrald Arch is a

15 more recent geological feature, and that while the origins lie in the

16 Tertiary, the arch itself is no older than the Pliocene and had a

17 pronounced effect in shaping the flow of the rivers in western Amazonia

18 (Toivonen et al. 2007). The Paleogeography Hypothesis predicts that sister

19 lineages will be found on either side of a geological arch and that in most

20 cases divergence will date to Middle Miocene or earlier, whereas on

21 either side of the Fitzcarrald Arch, divergence will date to the Pliocene

22 (Table 1; important Amazonian geological arches shown in Fig. 1). 
2 The Hydrogeology Hypothesis (Montoya-Burgos 2003) considers the role of

3 geological changes over the course of the Mio-Pliocene and Pleistocene

4 in the establishment of the modern drainage patterns and the vicariance

5 of populations of aquatic species (Lundberg et al. 1998). In this study the

6 definition of Hubert and Renno (2006) is used rather than the broader

7 definition of Montoya-Burgos (2003). Specifically, the hypothesis considers

8 a degree of isolation according to drainage basin, with watershed

9 breakdowns and headwater captures leading to a founding population

10 in the neighboring basin. Consequently, sister lineages will be found on

11 either side of watersheds in the headwaters of the catchments, and

12 lineages within one drainage basin will fall within a larger clade with

13 lineages from a neighboring basin. Evidence of populations being

14 structured by tributaries has been found in numerous species of

15 Neotropical fish (Montoya-Burgos 2003; Hubert and Renno 2006), frogs

16 (Garda and Cannatella 2007), and river turtles (Pearse et al. 2006).

18 The Refugia Hypothesis considers climatic change as the main driver of

19 diversification. The hypothesis states that episodic cooling events resulting

20 from Milankovitch cycles have caused rainfall over Amazonia to reduce,

21 leading to periodic reduction in river outflow and decline of rainforests.

22 Rainforest communities subsequently split into isolated refugia separated 
1 by arid pampas (Haffer 1969; van der Hammen 1975). These refugia are

2 considered to have led to divergence and areas of endemism from which

3 new lineages arose. Phylogeographic patterns attributed to glacial

4 refugia have been described in a variety of terrestrial taxa (Whitmore and

5 Prance 1987), but also in Neotropical fish (Hubert et al. 2007). The

6 hypothesis predicts that phylogeographic structure will agree with

7 patterns of endemism identified by Whitmore and Prance (1987) and

8 Hubert et al. (2007). While Aleixo (2004) considered predictions of the

9 Refugia Hypothesis to include a demographic expansion which took

10 place following the end of the Last Glacial Maximum (LGM) $(20,000$ years

11 BP) along with low genetic variability and shallow phylogeographic

12 structure, this only considers the influence of the LGM on shaping the

13 pattern of phylogenies. By contrast, Haffer (1997) claimed that the

14 Refugia Hypothesis is applicable to climatic change as far back as the

15 Tertiary. Consequently rejection of Aleixo's predictions, and rejection of

16 the role of the LGM, is not considered sufficient to reject the Refugia

17 Hypothesis.

18

$19 \quad 1.1$ Specific aims

20 Research interest in Amazonian phylogeography has greatly increased in

21 recent years (Antonelli et al. 2010). However, despite some thorough

22 investigations conducted predominantly on the phylogeography of 
1 icthyological and avifaunal communities (Lundberg et al. 1998; Montoya-

2 Burgos 2003; Fjeldså 1994; Nores 1999; Aleixo 2004; Lovejoy and Aruajo

3 2000; Hubert and Renno 2006; Hubert et al. 2007), there remains a paucity

4 of studies which evaluate the geological, climatic and hydrological

5 processes which have shaped the present pattern of biodiversity. The

6 otter makes for an interesting study animal due to its semi-aquatic/semi-

7 terrestrial habits, which both restrict it to riparian and lacustrine

8 environments yet enable it to travel some distance overland. This study first

9 investigates the degree of mitochondrial genetic diversity within the

10 endangered giant otter and determines the degree to which populations

11 are structured. Second, it investigates the evolutionary history of the

12 species by testing for evidence of the three hypotheses of Amazonian

13 diversification outlined above.

\section{2. Material and methods}

182.1 Sample collection, storage and DNA extraction

19 Sequence data from a total of 70 genetic samples distributed among

20 eight countries and four drainage basins were used in this study (Fig. 1 and

21 Appendix A). The sequence data originate from 34 sites and comprise a

22 composite of fecal and museum samples collected for this study, and 
1 sequences from the Brazilian Amazon and Pantanal reported by Garcia et

2 al. (2007). The majority of samples collected for this study were fecal in

3 origin, collected from the field in Bolivia, Peru and Guyana. These samples

4 consisted of $3-5 \mathrm{ml}$ of fresh spraint taken from latrines shortly $(<3 \mathrm{hrs})$ after

5 deposition and stored in $10 \mathrm{ml}$ of $90 \%$ ethanol. Museum samples consisted

6 of dried skin clippings, adhered tissue to skulls, teeth and bones, and were

7 collected and stored dry in sealed Eppendorf tubes or paper envelopes.

8 Tissue or fecal samples from captive animals of known provenance were

9 also collected and stored in $90 \%$ ethanol (the origin of each sample is

10 given in Appendix A). Fecal samples were extracted using the QIAamp ${ }^{\circledR}$

11 DNA Stool Mini Kit (Qiagen) following the manufacturer's protocol with

12 one modification; the incubation period with Buffer ASL was extended

13 overnight with agitation at $37^{\circ} \mathrm{C}$. Fresh tissue samples, museum skin

14 clippings, and adhered skull tissue were extracted using the DNeasy ${ }^{\circledR}$

15 Tissue Extraction Kit (Qiagen). DNA was extracted from bone and teeth

16 using the non-destructive guanidine method according to the protocol of

17 Rohland and Hofreiter (2007). All extraction of DNA from museum samples

18 was conducted in a dedicated room away from sources of

19 contamination. Filter tips were used throughout the study and all

20 equipment was regularly irradiated using UV light. Negative controls were

21 used in each batch of DNA extractions and in each PCR and agarose gel

22 run. 
$2 \quad 2.2$ DNA amplification and sequencing

3 The entire giant otter cytochrome b (1 140 bp) and control region (936 bp)

4 genes were amplified in six samples from disparate geographical sites

5 using the mustelid primers developed by Koepfli and Wayne (1998) and

6 primers developed in the Eurasian otter, Lutra lutra, by Mucci et al. (1999).

7 Variable regions were identified, resulting in $612 \mathrm{bp}$ at the $3^{\prime}$ end of

8 cytochrome $\mathrm{b}$ and $383 \mathrm{bp}$ at the $5^{\prime}$ end of control region being selected

9 for use in this study. Primers specific to the giant otter were then designed

10 to amplify this 995 bp sequence, amplifying six overlapping fragments of

11 300 bp each in order to obtain sequence from highly degraded fecal

12 and museum DNA (see Appendix B for primer sequences). Amplification

13 was carried out in $10 \mu \mathrm{l}$ PCR reactions containing $3 \mu$ template DNA, $3 \mu \mathrm{l}$

14 of $25 \mu \mathrm{M}$ primer solution, $0.2 \mu \mathrm{g}$ bovine serum albumen, autoclaved Milli-Q

15 water and $4 \mu \mathrm{V}$ Qiagen ${ }^{\circledR}$ multiplex PCR kit (containing master mix,

16 HotStarTaq, $\mathrm{MgCl}_{2}$, dNTPs and PCR buffer). PCR was performed using a 95

$17{ }^{\circ} \mathrm{C}$ denaturing step for $12 \mathrm{~min}$ followed by 40 cycles of denaturing at $94{ }^{\circ} \mathrm{C}$

18 for $30 \mathrm{~s}$, annealing at $54{ }^{\circ} \mathrm{C}$ for $1 \mathrm{~min} 30 \mathrm{~s}$, and extension at $72{ }^{\circ} \mathrm{C}$ for $1 \mathrm{~min}$

$1930 \mathrm{~s}$, with a $2{ }^{\circ} \mathrm{C}$ drop in annealing temperature every 10 cycles, and a

20 final extension period at $60^{\circ} \mathrm{C}$ for $30 \mathrm{~min}$. Following amplification, PCR

21 products were run on a $2 \%$ standard agarose gel stained with $0.02 \mu \mathrm{l}$ of 10

$22 \mathrm{mg} / \mathrm{ml}$ ethidium bromide and the bands excised before extraction of the 
1 product using the QIAquick® Gel Extraction Kit (Qiagen). Sequencing

2 reactions took place in a reaction volume of $15 \mu \mathrm{l}$ with $5 \mu \mathrm{lPCR}$ product, 1

$3 \mu$ l BigDye Terminator Cycle Sequencing Kit (Applied Biosystems), $5 \mu$ Better

4 Buffer (Web Scientific), $3 \mu \mathrm{l} 0.8 \mu \mathrm{M}$ individual primer solution and $1 \mu \mathrm{l}$

5 ddH20. The sequencing reaction involved a $94{ }^{\circ} \mathrm{C}$ denaturing step for 3

6 min followed by 25 cycles of denaturing at $94{ }^{\circ} \mathrm{C}$ for $15 \mathrm{~s}$, annealing at 50

$7{ }^{\circ} \mathrm{C}$ for $10 \mathrm{~s}$ with extension at $60^{\circ} \mathrm{C}$ for $4 \mathrm{~min}$, and a final extension period at

$860^{\circ} \mathrm{C}$ for $5 \mathrm{~min}$. Following sequencing, the sequenced product was

9 cleaned using washes of $100 \%$ ethanol and $125 \mu \mathrm{M}$ EDTA followed by $70 \%$

10 ethanol precipitation and centrifugation at $30000 \times$ gfor 30 min and 16,500

$11 \mathrm{rpm}$ for $15 \mathrm{~min}$. Sequenced product (1.2 $\mu$ l) was run on an $A B \mid 3100$

12 Sequencer (Applied Biosystems) with $9 \mu$ formamide.

142.3 Analysis of genetic variability and phylogeographic

15 structure

16 The chromatograms of all sequences were checked by eye and edited

17 using Sequencher 4.8 (Gene Codes Corporation). A conservative

18 approach was taken in which a polymorphism had to be evident in both

19 forward and reverse strands to be accepted. Sequences were checked

20 against reference giant otter sequences using BLAST searches. The six

21 fragments of control region and cytochrome $b$ for each sample were

22 concatenated and these sequences were aligned with the 30 sequences 
1 from Garcia et al. (2007) in Sequencher. All new sequences have been

2 deposited in GenBank (accession numbers JN252256-JN252295).

4 Nucleotide and haplotypic diversity and FST values were calculated using

5 DNASP 5 (Librado and Rozas 2009). The program Modeltest 3.6 (Posada

6 and Crandall 1998) was used to select the model of nucleotide

7 substitution that best fit the data. Cytochrome $b$ and control region

8 fragments were analyzed both separately and as concatenated

9 sequence. In each case the model of evolution selected by Akaike

10 Information Criterion was HKY+I+G with equal proportion of invariable sites

11 (I) and transition/transversion ratios (ti/tv) for both control region and

12 cytochrome b $(I=0.805$ and $0.839, \mathrm{ti} / \mathrm{tv}=7.684$ and 7.353 respectively). To

13 establish that these genes did not have differing phylogenetic signals, ML

14 trees with 100 bootstrap replicates were generated separately for each

15 gene partition and the topology of the consensus trees compared. The

16 trees of both genes exhibited the same deep splits in topology, suggesting

17 that the two genes could be concatenated for phylogenetic and

18 network analysis.

19

20 Phylogenetic relationships among haplotypes were analyzed using

21 MrBayes 3.1 (Ronquist and Huelsenbeck 2003). Sequence data were run

22 under a variety of evolutionary models and the best-fitting model was 
1 selected using Bayes factors (Kass and Raftery 1995). This selected the HKY

2 model of evolution, corroborating the Modeltest result. Four simultaneous

3 chains were run for 13 million generations, sampling every $100^{\text {th }}$ generation

4 and excluding the initial 13,000 runs as burn-in before plotting the

5 consensus tree. The sea otter, Enhydra lutris, and the Eurasian otter, Lutra

6 Iutra, were used as outgroups to root the tree. The MrBayes analysis was

7 run twice, yielding the same topology in each case. To test the accuracy

8 with which phylogeny could be inferred using the sequence data, the

9 Bayesian approach was compared with the ML method implemented

10 using PhyML 3.0 (Guindon and Gascuel 2003) in which node support was

11 verified by bootstrapping for 1000 replications. The relationships between

12 populations were also resolved using the statistical parsimony approach

13 implemented using the program TCS (Clement et al. 2000). Up to $947 \mathrm{bp}$

14 of concatenated cytochrome b/control region was sequenced in each

15 sample. However, the sequences from the study by Garcia et al. (2007)

16 were 129 bp shorter than our own and one sample from the River Madeira

17 was sequenced to $482 \mathrm{bp}$.

19 Phylogeographic structure was tested using SAMOVA 1.0 (Dupanloup et

20 al. 2002). The program was run with the number of populations prior (K) of

21 between 2 and 20, with 100 simulations per K. No populations were

22 predetermined and each sampling site was considered alone as a 
1 'population' for the sake of the test. The actual number of

2 phylogeographic groups was identified using the difference between the

3 measure of among-group variation for each $K\left(\Delta F_{C T}\right)$ (Dupanloup et al.

4 2002). To test for a pattern of isolation by distance, we first partitioned the

5 samples into 11 sampling regions, determined by continuous aquatic

6 provinces, such as the Essequibo basin, the River Negro and tributaries

7 and restricted to $1000 \mathrm{~km} 2$. The geographical coordinates were taken as

8 the point equidistant from all sampling sites within the 'sampling region'

9 and geographic distances among sampling regions calculated. A Mantel

10 test was performed in Arlequin 3.0 (Excoffier ef al. 2005) using geographic

11 distance and $F_{S T} /\left(1-F_{S T}\right)$.

132.4 Molecular clock calibration and estimation of phylogroup

14 divergence times

15 Evidence of fixed rate evolution among lineages was also tested for using

16 the likelihood ratio test. This was conducted in PAUP*4.0 (Swofford 2002)

17 using the model of evolution determined by Modeltest to compare the

18 likelihood scores of strict clock and non-clock models. The significance of

19 the resulting test statistic was determined using a Chi-squared test, which

20 produced a highly significant result $(\mathrm{P}<0.001)$, rejecting the strict clock 21 model. 
2 Timing of phylogroup divergence was resolved using Bayesian coalescent

3 analysis implemented with the software BEAST 1.5.3 (Drummond and

4 Rambaut 2007). The protocol of Lebarbenchon et al. (2010) was followed

5 in which the program was run using three different molecular clock

6 models (strict clock, relaxed uncorrelated exponential, and relaxed

7 uncorrelated lognormal) and three different coalescent priors (constant

8 size, exponential growth, and expansion growth). Results were compared

9 against the null model (strict clock, constant size) using Bayes factor in

10 Tracer 1.4 (Drummond and Rambaut 2007), in which a log 10 Bayes factor

11 of greater than 1 was considered evidence in favor of the alternative

12 model (Kass and Raftery 1995).

14 Three outgroups were used to root the phylogenetic tree. These

15 comprised two lutrines (the sea otter and Eurasian otter) and one

16 musteline (the stoat, Mustela erminea). Taxonomic groupings were

17 specified using the phylogenetic relationships of the Mustelidae reported

18 by Koepfli et al. (2008). In setting nodal calibration points, the lognormal

19 distribution date range was used as recommended by Ho (2007). In

20 setting constraints using the lognormal distribution, the fossil date was

21 considered an absolute lower bound, with the 95\% highest posterior

22 density (HPD) lying between the fossil date and a soft upper bound two 
1 million years earlier. The entire tree was constrained by a lognormal

2 distribution with an absolute lower bound of $5.3 \mathrm{Ma}$, considered the

3 earliest fossil record of the genus Mustela (The Paleobiology database

4 http://paleodb.org). The earliest appearance of the genus Lutra, dating

5 to $3.6 \mathrm{Ma}$, was used as a minimum lower bound to date the split between

6 the sea otter and the Eurasian otter (Willemsen 1992). The split between

7 the giant otter clade and the sea otter and Eurasian otter clade is

8 considered to have occurred early in the evolutionary history of the

9 Iutrines (Koepfli and Wayne 1998; Koepfli et al. 2008). However, the earliest

10 fossil record of the giant otter's putative ancestor, Satherium piscinarium,

11 dates to no earlier than 4.7 Ma in North America (Bjork 1973; Lindsay et al.

12 1984). Despite morphometric analysis supporting a close relationship

13 between Satherium and Pteronura (Prevosti and Ferrero 2008), the

14 ancestry of Satherium to Pteronura remains controversial. Consequently,

15 fossil records of Satherium were not used to constrain the tree. BEAST was

16 run for 10 million generations, sampling every $1000^{\text {th }}$ iteration with a burn-in

17 of $10 \%$. Two chains were run and convergence checked using Tracer.

18 Runs were performed for each clock model and coalescent priors and

19 Bayes factor between the likelihoods determined using a bootstrap of

201000. 
1 Evidence of recent population expansion, as predicted by the

2 Pleistocene Refugia hypothesis, was investigated by testing Fu's Fs (Fu

3 1997) in the control region sequences of each of the phylogroups

4 resolved using SAMOVA. A significantly negative $F_{S}$ is considered to be

5 evidence against population stasis. The nature of the demographic

6 change was then characterized by comparing mismatch distributions of

7 sequence differences (Rogers 1995). Both Fu's Fs and mismatch

8 distributions were calculated using Arlequin. The dates of population

9 expansions were estimated using the method of Rogers and Harpending

10 (1992). The demographic expansion parameter tau ( $\mathrm{T})$, was estimated in

11 Arlequin and used to calculate time of expansion $(t)$ using the formula $\mathrm{T}=$

$122 u t$, in which $u=\mu k$ where $\mu$ is the mutation rate per site per year and $k$ is

13 the length of the sequence. We used the $1.92 \%$ per million years

14 sequence divergence rate between the weasel (Mustela nivalis) and

15 ermine (Mustela erminea) calculated by Marmi et al. (2004), but due to

16 evidence that mutation rates are higher in tropical species (Weir and

17 Schluter 2007), we also used the faster $10 \%$ per million years divergence

18 rate calculated by Víla et al. (1999) for the split between grey wolves

19 (Canis lupus) and coyotes (Canis latrans).

22 3. Results 
2 3.1 Genetic variation and phylogeographic structure

3 Fifty-nine polymorphic sites were identified in the mtDNA sequence

4 spanning up to $946 \mathrm{bp}$ of cytochrome $\mathrm{b}$ and the control region. Overall

5 haplotype diversity was high at 0.93 with 41 haplotypes resolved, and

6 nucleotide diversity was also high $(\pi=0.015)$. Genetic diversity was high in

7 all of the phylogroups (described below) except for the Pantanal ( $h=$

8 0.44), where a single haplotype dominated $75 \%$ of all sequences (A table

9 of mutational differences among haplotypes is given in Appendix C)

11 Four phylogroups were resolved in SAMOVA using the $\Delta F_{C T}$ method,

12 comprising the Iténez and River Uruá (1); the Madre de Dios and Madeira

13 (2); the Pantanal (3); and the Amazon, the Orinoco and the Guianas (4).

14 This grouping explained $65 \%$ of the variation, with $18 \%$ explained by

15 among populations within-group variation, and $17 \%$ due to within-

16 population differences. The phylogeographic clustering resolved with

17 SAMOVA was supported by the statistical parsimony network (Fig. 2),

18 which revealed three differentiated clusters in the south-west of the giant

19 otter's range. Genetic distances among phylogroups were high, with $F_{S T}$

20 values ranging from 0.64 to 0.74 , implying a strong degree of structuring

21 (Table 2). 
1 Within the Amazon/Orinoco/Guianas phylogroup, three weakly-supported

2 sub-groups were identified with haplotype network analysis, namely the

3 Central Amazon and Guianas; the Orinoco; and the Upper Amazon (Fig.

4 2). However, Bayesian phylogenetic reconstruction only differentiated two

5 subclades: the Guianas and Central Amazon, and the Orinoco and Upper

6 Amazon. Maximum likelihood analysis failed to resolve subdivisions within

7 the phylogroup (Fig. 3).

8

9 The relationship of the Madre de Dios and Madeira populations within

10 their phylogroup was unresolved. They cluster as a single phylogeographic

11 group in the network analysis. However, there are a number of mutational

12 differences between the Madre de Dios and Madeira sequences (Fig. 2,

13 Appendix C). When $K$ in SAMOVA is increased to five, the Madre de Dios

14 and Madeira sequence sets are split into two distinct phylogeographic

15 groupings. The relationship is also not well resolved either with Bayesian or

16 maximum likelihood phylogenetic reconstructions (Fig. 3), nor is the

17 relationship of the phylogroup to the lténez, becoming paraphyletic in $\mathrm{ML}$

18 and BEAST phylogenetic reconstructions (Fig. 3, Fig. 4).

19

20 Repeated analysis using different mustelid outgroups (Eira barbara,

21 Mustela erminea) produced the same topology, as did performing 
1 unrooted phylogenetic analyses, implying that the resulting topology is

2 unlikely to be due to long branch attraction to the outgroup sequences.

3

$4 \quad 3.2$ Phylogroup divergence times

5 The null clock model: strict clock (likelihood -2995.11), was rejected by

6 both the relaxed exponential $(-2984.36)$ and the relaxed lognormal (-

7 2993.25) clocks with Bayes factors $>20$. By contrast, the comparison of

8 coalescence priors did not lead to the rejection of the null model:

9 constant growth (-2995.11) by either expansion growth (-2994.67) or

10 exponential growth (-2994.92) (Bayes factors <2). Consequently, the most

11 appropriate model used to estimate timings of phylogroup divergence

12 was the relaxed exponential clock with constant growth.

14 Two stages of divergence can be observed from the molecular dating.

15 Firstly, the Iténez and Madre de Dios/Madeira phylogroups diverged from

16 the rest of the giant otter populations during the Early Pleistocene 1.24-

17 1.69 Ma (0.72-3.1 Ma 95\% HPD). Subsequently, the Pantanal and

18 Amazon/Orinoco/Guianas phylogroups diverged from one another 0.88

19 Ma (0.2-1.6 Ma 95\% HPD) during the Middle Pleistocene (Fig. 4, Appendix

20 D).

22 3.3 Demographic expansion 
1 Analysis of the demographic history of the phylogroups produced

2 ambiguous results. The neutrality test suggested expansions had occurred

3 in all four phylogroups $\left(F_{S}=-3.58\right.$ to $\left.-26.66, P=0.01\right)$. Characterizing the

4 expansion further with mismatch analysis, a smooth wave with an

5 expected distribution close to the observed was recorded for the

6 Amazon/Orinoco/Guianas and Pantanal phylogroups, indicative of a

7 population which had recently expanded (Fig. 5). The rough, multimodal

8 distribution of the Madre de Dios/Madeira and Iténez phylogroups, by

9 contrast suggests a lack of recent population growth. However, low

10 sample sizes in three of the phylogroups may have reduced the power of

11 the test to discern a demographic expansion. The phylogroups were

12 calculated to have expanded between 672,000 and 407,000 years BP

13 during the Middle Pleistocene using the mustelid divergence rate of

14 Marmi et al. (2004). The faster canid divergence rate of Víla et al (1999)

15 yielded a lower bound of between 130,000 and 66,000 years BP.

\section{$17 \quad 3.4$ Isolation by distance}

18 A weak relationship between the geographic and genetic distances

19 among the 11 sampling regions $\left(R^{2}=0.11\right)$ was not found to be significant

$20(P=0.06)$, indicating that isolation by distance is unlikely to have

21 generated the observed phylogeographic structure. 
2 4. Discussion

4 4.1 Genetic variation and phylogeographic structure in the 5 giant otter

6 This study reveals a high degree of genetic diversity in the giant otter

7 compared with other lutrines. Ferrando et al. (2004) found levels of

8 haplotype diversity of 0.16 (number of samples $[n]=73$ ) with a single

9 haplotype dominating throughout Europe and Russia in the Eurasian otter,

10 Lutra lutra. Similarly, the heavily persecuted sea otter, Enhydra lutris, shows

11 a haplotypic diversity of only 0.18-0.4 $(n=24-36)$ (Larson et al. 2002). This

12 disparity may also reflect the faster rate of molecular evolution and lower

13 extinction rate of lineages recorded in many tropical species, including

14 mammals (Weir and Schluter 2007; Gillman et al. 2009). However,

15 haplotypic diversity in the giant otter is also higher than that so far 16 recorded in the Neotropical otter, Lontra longicaudis, $h=0.82 n=20$

17 (Trinca et al. 2007) and southern river otter, Lontra provocax, $h=0.71, n=$ 1825 (Centron et al. 2008). Our results also contrast with the lower haplotype 19 and nucleotide diversities previously found in the giant otter by Garcia et

20 al (2007), $(h=0.87, \pi=0.006)$, which was limited geographically to the

21 central Amazon and one site in the Pantanal and restricted in terms of 
1 sample size $(n=30)$. The level of diversity found in our study was also high

2 throughout three of the phylogeographic groups of populations (Table 3)

3 and this remains the case when museum samples dating to the middle of

4 the last century are removed. The high levels of mitochondrial genetic

5 diversity we observed in the Amazon/Orinoco/Guianas, Iténez, and

6 Madre de Dios/Madeira phylogroups are somewhat surprising given the

7 extent of the demographic decline known to have occurred, and may be

8 partly attributed to the giant otter's longevity (up to 13 years recorded in

9 the wild) and long generation time (reported as seven years in

10 Groenendijk et al. 2004) buffering attrition of genetic diversity (Hailer et al.

11 2006). However, the lower haplotype and nucleotide diversity seen in the

12 Pantanal phylogroup, with a single dominant haplotype found in nine of

13 the twelve individuals sequenced, may be due to a more sustained level

14 of persecution. Between 1960 and 1969 12,390 skins were exported from

15 the Brazilian Pantanal alone, constituting $24 \%$ of the total Brazilian export

16 during this time (Harris et al. 2005).

18 The genetic diversity is not evenly geographically distributed and despite

19 the smaller total area, lower sample numbers, and number of sampling

20 sites, the south-western fringe of the giant otter's range comprises three of

21 the four phylogroups and contains a similar level of mean haplotypic

22 diversity $(h=0.87, \pi=0.015)$ to the entirety of northern Amazonia $(h=0.88$, 
$1 \pi=0.0067)$. No strong support is given to the previous subspecies division

2 between the giant otter populations of the Parana'-Paraguay drainage,

3 P. b. paranensis, and the Amazon basin, P. b. brasiliensis, agreeing with

4 Garcia et al. (2007). In contrast, the phylogroups of the Iténez and Madre

5 de Dios/Madeira within the Amazon basin itself appear distinct from other

6 Amazonian populations. Sample 2.11 (origin: River Negro, Garcia et al.

7 2007) is unusual in that it exhibits Haplotype 1, the most common

8 haplotype in the Pantanal. The most parsimonious explanation is likely to

9 be that of convergent evolution rather than representing evidence of

10 migration between the Pantanal and River Negro.

124.2 Support for the hypotheses of divergence

13 4.2.1 Paleogeography Hypothesis

14 The impact of the formation of geological arches in driving vicariance in

15 South American species has been largely unacknowledged until recently

16 (Räsänen et al. 1990) and remains controversial (Rossetti et al. 2005;

17 Wesselingh and Salo 2006). Da Silva and Patton (1998) provide evidence

18 of phylogeographic pattern being determined by tectonic forces in

19 terrestrial mammals on either side of the Iquitos Arch. The uplift of the

20 Vaupes Arch in separating the Amazon and Orinoco drainages has also

21 been considered a driver of the divergence of piranhas in the genus

22 Prochilodus by Sivasundar et al. (2001). Within the giant otter, the strong 
1 pattern of divergence seen between the phylogroups of the Upper

2 Madeira and the Amazon/Orinoco/Guianas might be considered

3 evidence of a vicariance event in which any freshwater contact between

4 the Amazon tributary, the River Ucayali, and the Upper Madeira tributary,

5 the River Madre de Dios, would have been broken by the formation of the

6 Fitzcarrald Arch. This region has remained geologically active into the Late

7 Quaternary (Latrubesse and Rancy 2000), with uplift of the Fitzcarrald Arch

8 continuing into the Pliocene (Roddaz et al 2010). Da Silva and Patton

9 (1998) resolved divergence times between lineages of between 1-3 million

10 years, which they considered to have been driven by the impact of

11 Andes foreland dynamics on the landscape of western Amazonia rather

12 than by climatic change. The rivers of the region are particularly dynamic

13 (Toivonen et al. 2007), with striking shifts in flow recorded over very recent

14 geological time. The River Beni for instance, one of the principal tributaries

15 of the River Madeira, has migrated anticlockwise over the course of the

16 Holocene leading to a change in flow orientation of 45 degrees over no

17 more than 10,000 years in response to the uplifting Andes piedmont

18 (Dumont 1996). Wilkinson et al. (2007) have pointed out that such

19 dynamic behavior by river courses and periodic river-switching events

20 may lead to fragmentation and a degree of isolation of riparian

21 populations. 
1 Molecular dating of the divergence time between giant otter lineages in

2 the Upper Amazon and Upper Madeira cannot rule out the role of the

3 Paleogeography Hypothesis, with complete divergence of the

4 phylogroups occurring around 1.24 Ma. However, the likelihood of the

5 Vaupes Arch influencing the divergence of Amazon and Orinoco

6 subclades or the Michicola Arch influencing the Pantanal/lténez split is

7 extremely low due to the very old (Mesozoic) age of these structures

8 (Limarino and Spalleti 2006; Rossetti et al. 2005).

$10 \quad$ 4.2.2 Hydrogeology Hypothesis

11 The Hydrogeology Hypothesis, according to the definition of Hubert and

12 Renno (2006), states that a headwater capture event or watershed

13 breakdown will have led to the colonization of a neighboring drainage

14 basin and subsequent retraction of the headwaters will lead to

15 vicariance. It predicts that lineages within one drainage basin will fall

16 within a larger clade with lineages from a neighboring basin. The

17 relationships among the subclades of the Amazon/Orinoco/Guianas

18 phylogroup suggest that the giant otter populations of the Orinoco,

19 Guianas, and Upper Amazon were founded from a Central Amazon

20 population and subsequently diverged from one another through partial

21 isolation. While there are freshwater connections among all three basins,

22 climatic change may have both facilitated movement among the basins 
1 during warmer, wetter periods and reduced inter-basin dispersal during

2 colder, more arid periods. However, this hypothesis is insufficient to explain

3 the divergence of the Madre de Dios/Madeira, the

4 Amazon/Orinoco/Guianas, and the Iténez phylogroups from one another.

5 While the Amazon/Parana'-Paraguay watershed is considered to have

6 formed in the Late Miocene (Lundberg et al. 1998; Montoya-Burgos 2003),

7 much younger ages of divergence between fish populations in Amazon

8 and Parana'-Paraguay basins of between 0.8 and 2 Ma have been found

9 in both the catfish Pseudoplatysoma (Torrico et al. 2009) and black-bellied

10 piranha Serrasalmus (Hubert et al. 2007), which are considered to have

11 been the result of headwater capture. These dates are broadly consistent

12 with those derived from the divergence of the giant otter Pantanal

13 phylogroup from the Amazon/Orinoco/Guianas within the giant otter (0.88

$14 \mathrm{Ma}, 1.60-0.38 \mathrm{Ma} 95 \% \mathrm{HPD})$ and could constitute evidence for the

15 Hydrogeology Hypothesis.

\section{4.2.3 Refugia Hypothesis}

18 The phylogeographic pattern identified in the giant otter does partially

19 correlate with a pattern of Pleistocene refugia identified in terrestrial

20 fauna and flora by Whitmore and Prance (1987) (Fig. 6). The Iténez

21 phylogroup overlaps the Aripuanã Refugium on the Brazilian Shield, and

22 the Madre de Dios sub-group falls within the Inambari Refugium in the 
1 immediate Andes forebasin. The Orinoco and Guianas sub-groups may

2 also overlap with refugia. The Pantanal phylogroup does not correspond

3 with any refugium. Hubert et al. (2007) and Renno et al. (2006) considered

4 the sub-basins of the Iténez and Madre de Dios to have been aquatic

5 refugia during the Pleistocene, leading to divergence in piranha

6 (Serrasalmus), and bass, (Cichla).

8 The divergence dates inferred among the giant otter phylogroups or sub-

9 groups do not correlate with the last glaciation, the Würm glaciation

$10(10,000-80,000$ years BP), and evidence from the mismatch analysis in the

11 giant otter phylogroups does not suggest a recent expansion following the

12 LGM, despite accounting for a possible rapid rate of evolution using the

13 faster canid rate. Instead, the expansions are likely to have occurred

14 during the Middle Pleistocene. Other studies of mammals in Amazonia

15 have similarly failed to find evidence of divergence of phylogroups during

16 the last glaciation and range expansion succeeding it (Gonzalez et al.

17 1998; Culver et al. 2000; Lessa et al. 2003). While discounting the role of the

18 LGM, the dates of phylogroup divergence do not rule out the possibility of

19 Plio-Pleistocene climate change driving the observed pattern. While the

20 climate of South America and the corresponding vegetation structure

21 over the last five million years are still debated, evidence from a variety of

22 sources seems to suggest that whereas the Early-Middle Pliocene was 
1 wetter and warmer by as much as $3{ }^{\circ} \mathrm{C}$, exhibiting constant El Niño-type

2 conditions with sea level up to $35 \mathrm{~m}$ above present levels, global cooling

3 began in the Late Pliocene as early as $3 \mathrm{Ma}$ (Sloan et al 1996; Molnar and

4 Cane 2007). In contrast to evidence initially put forward by Zarate and

5 Fazenda (1989) of a warm, wet Plio-Pleistocene, Ortiz Jaureguizar et al.

6 (1995) in Vizcaino et al (2004) cite a reduction in the number of fossil

7 rodent burrows in the Argentine strata around 2.4 Ma concordant with the

8 onset of cooler glacial conditions. Leroy and Dupont (1994) provide

9 evidence of aridity from North Africa during the Late Pliocene (3.7-1.7 Ma)

10 in the pollen record, suggesting a reduction in forest type assemblages.

11 This is backed up by evidence of a significant cooling of global ocean

12 surfaces around 2.1 Ma from planktonic discoaster fossils (Chapman and

13 Chepstow-Lusty 1997). Several studies of antarctic sediments suggest the

14 onset of cyclical glaciation began during the Late Pliocene 2.2-2.9 Ma

15 (Whitehead and McMinn 2002; Rebesco and Camerlenghi 2008), while

16 deep sea sediment cores provide evidence of a marked decline in sea

17 surface temperature from 2.1-1.9 Ma (Marlow et al. 2000).

19 Comparative phylogeographic studies in other large mammalian taxa are

20 lacking. Nevertheless there are several studies which reveal similar

21 divergence times to the giant otter among deep lineage splits.

22 Divergence of major lineages within the crab-eating fox (Cerdocyon 
1 thous) (Tchaitcka et al. 2007), several small South American cat species

2 (Johnson et al. 1999), and brocket deer (genus Mazama) (Barbante

3 Duarte et al. 2008) occurred during the Plio-Pleistocene between 3.7 and

$40.4 \mathrm{Ma}$, again suggested in response to climate shifts.

5

$6 \quad 4.3$ Conclusion

7 Following testing of three hypotheses of Amazonian diversification, it

8 appears that the phylogeographic pattern observed in the giant otter

9 might be the result of multiple drivers. The molecular dating suggests that

10 due to the long time span over which the four phylogroups diverged from

11 one another (1.69-0.61 Ma, 3.1-0.25 95\% HPD), no single paleoclimatic or

12 paleoenvironmental event was likely to be responsible for the pattern. The

13 continued uplift of the Fitzcarrald Arch during the Plio-Pleistocene and the

14 ensuing reordering of fluvial systems driven by continuing geological

15 activity may have been a factor in driving the deepest phylogenetic split

16 in the giant otter. But these alterations in drainage pattern would also

17 have occurred during a time in which the climate of South America

18 became periodically cooler and more arid (Ortiz Jaureguizar et al. 1995;

19 Leroy and Dupont 1994; Chapman and Chepstow-Lusty 1997). Reduced

20 rainfall would have led to rivers changing from predominantly

21 depositional to high energy erosional. The preference of the giant otter for

22 slow moving creeks and ponds over fast-flowing rivers (Duplaix 1980; 
1 Zambrana Rojas 2004) suggests that a shift to the high energy rivers would

2 have reduced optimal habitat for the species. Furthermore, the number of

3 inter-drainage connection routes would have shrunk, leading to partial

4 isolation of some populations. The phylogeographic pattern is then likely

5 to have been preserved through isolation by distance and a male

6 exogamous dispersal system (Groenendijk and Hajek 2006).

$8 \quad 4.4$ Conservation

9 In terms of prioritizing conservation effort within the species, this study has

10 identified four distinct lineages within the giant otter which broadly

11 correspond to four geographic regions. Preservation of genetic diversity

12 and evolutionary potential within the species will rely on ensuring

13 populations within each of these four regions are targeted for

14 conservation.

15

16 Further analysis using nuclear markers will be required to fully resolve

17 whether the four lineages constitute evolutionary significant units (Moritz

18 2002). However, focusing attention on the southern fringe of the range,

19 where a disproportionate amount of the species' total mitochondrial DNA

20 diversity is found, may preserve the greatest amount of diversity in the

21 smallest geographical area. Some recent experimental evidence supports

22 the view that conservation planning targeted to preserve the deepest 
1 branched lineages within a species is an effective way of ensuring the

2 survival of that species (Rauch and Bar Yann 2004). This study has

3 determined that the giant otter exhibits high total mitochondrial

4 haplotype diversity and that possibly owing to a long generation time and

5 a number of small, geographically disparate, surviving populations, it has

6 not been left genetically depauperate in three of the four phylogroups

7 despite the population crash of the last century. However, despite the

8 fact that the giant otter population appears to be recovering in the

9 Pantanal (Tomas et al. 2000), the low haplotypic diversity seen there is of

10 concern and may suggest that this phylogroup is the most fragile of them

11 all. Our study lends support to previous research showing evidence of

12 endemism in fish (Hrbek et al. 2005; Renno et al. 2006) and river dolphins

13 (Banguera-Hinestroza et al. 2002) in the tributaries of the Upper Madeira

14 and south-western Amazonia, highlighting the biogeographical

15 importance of this biome for aquatic species across a broad range of

16 taxa.

\section{Acknowledgements}

20 This paper is dedicated to Dr. Bill Jordan, who tragically passed away

21 before the manuscript came to print. Bill's great patience and knowledge

22 were instrumental in the development of this work and he will be greatly 
1 missed both as an astute scientist and as a friend. Many thanks go to all

2 the many collaborators who have helped to provide samples for this

3 study, especially to Maribel Recharte and Mark Bowler, Lisa Davenport,

4 Isla Hoffmann-Heap, Adriana Salinas and Niall McCann. Many thanks are

5 also due to a large number of keepers, curators, and institutions for

6 providing DNA samples. These include Sheila Sykes-Gatz and Volker Gatz

7 and Dortmund Zoo; Nathalie Lindholm and Dallas World Aquarium; Terry

8 Webb and Miami Metro Zoo; Carol Benneto and the Chestnut Centre;

9 Paula Jenkins and the Natural History Museum, London; Jacques Cuisin

10 and the Museum National d'Histoire Naturelle, Paris; Maureen Flannery

11 and the Californian Academy of Science; Judith Chupasko and the

12 Harvard Museum of Comparative Zoology; Linda Gordon and the

13 Smithsonian Institution, Washington; Eileen Westwig and the American

14 Museum of Natural History, New York; Judith Eger and the Royal Ontario

15 Museum; Olavi Grönwall and the Swedish Museum of Natural History,

16 Stockholm; Beatrice Blöchlinger and the Naturhistorisches Museum, Bern;

17 Paulo Agnelli and the Museo Zoologico la Specola, Florence; Enrique

18 Gonzalez and the Museo Nacional de Historia Natural, Monte Video; and

19 to Bruce Patterson and the Field Museum. Special mention must go to

20 Jessica Groenendijk and Frank Hajek for advice on dispersal in giant

21 otters. Ken Campbell and Martin Roddaz provided helpful comments and

22 advice on the geology of South America in the Pliocene and John Flynn, 
1 John Terborgh, and Francisco Prevosti provided valuable suggestions on

2 the origin and spread of Pteronura in South America. Klaus-Peter Koepfli

3 and Claudine Montgelard provided generous advice on running BEAST.

4 This research was predominantly funded by a NERC studentship award, as

5 well as the Gilchrist Educational Trust Expeditions Award, Linnaean

6 Society's Percy Sladen Memorial Fund and ZSL's Daisy Balogh Travel

7 Award.

8

9 Permits were obtained for sampling from a number of national

10 organizations. Guyana: Environmental Protection Agency (EPA). Permit

11 reference number 101208 BR101.

12 Bolivia: Ministerio de Desarollo Rural, Agropecuario y Medio Ambiente

13 Servicio Nacional de Sanidad Agropecuaria e Inocuidad Alimentaria

14 (SENASAG). Permit Number 008025.

15 Peru: Instituto Nacional de Recursos Naturales (INRENA). Permit Number

16031 C/C-2008-INRENA-IANP

18 References

19 Aleixo, A., 2004. Historical diversification of a terra-firme forest bird

20 superspecies: a phylogeographic perspective on the role of different

21 hypotheses of Amazonian diversification. Evolution, 58, 1303-1317. 
1 Antonelli, A., Quijada-Mascareñas, A., Crawford, A.J., Bates, J.M.,

2 Velazco, P.M., Wüster, W., 2010. Molecular studies and phylogeography of

3 Amazonian tetrapods and their relation to geological and climatic

4 models, in: Hoorn, C., Wesselingh, F., (Eds) Amazonia, landscape and

5 species evolution: a look into the past. Wiley-Blackwell, Oxford, pp 3866404.

8 Avise, J.C., 2000. Phylogeography: The History and Formation of Species.

9 Harvard University Press, Cambridge, MA.

11 Banguera-Hinestroza, E., Cardenas, H., Ruiz-Garcia, M., Marmontel, M.,

12 Gaitá, E., Vázquez, R., García-Vallejo, F., 2002. Molecular identification of

13 evolutionarily significant units in the Amazon river dolphin Inia sp.

14 (Cetacea: Iniidae). Heredity 93, 312-322.

16 Barbanti Duarte, J.M., González, S., Maldonado, J.E., 2008. The surprising

17 evolutionary history of South American deer. Molecular Phylogenetics and

18 Evolution 49, 17-22.

20 Bjork, P.R., 1973. Additional carnivores from the Rexroad Formation (Upper

21 Pliocene) of southwestern Kansas. Transactions of the Kansas Academy of

22 Science 76, 24-38. 
2 Carter, S.K., Rosas, F.C.W., 1997. Biology and conservation of the giant

3 otter Pteronura brasiliensis. Mammal Review 27, 1-26.

4

5 Centron, D., Ramirez, B., Fasola, L., MacDonald, D.W., Chehébar, C.,

6 Schiavini, A., Cassini, M.H., 2008. Diversity of mtDNA in Southern River Otter

7 (Lontra provocax) from Argentinean Patagonia. Journal of Heredity

8 doi:10.1093/jhered/esm 117.

10 Chapman, M.R., Chepstow-Lusty, A.J., 1997. Late Pliocene climatic

11 change and the global extinction of the discoasters: an independent

12 assessment using oxygen isotope records. Palaeogeography,

13 Palaeoclimatology, Palaeoecology 134, 109-125.

15 Chazdon, R.L., Whitmore, T.C., 2002. Foundations of Tropical Forest Biology:

16 Classic Papers with Commentaries. University of Chicago Press, Chicago.

18 Clement, M., Posada, D., Crandall, K.A., 2000. TCS: a computer program

19 to estimate gene genealogies. Molecular Ecology 9, 1657-1660.

21 Coates, A.G., Collins, L.S., Aubry, M.P., Berggren, W.A., 2004. The geology

22 of the Darien, Panama, and the late Miocene-Pliocene collision of the 
1 Panama arc with northwestern South America. Geological Society of

2 America Bulletin 116, 1327-1344.

3

4 Culver, M., Johnson, W.E., Pecon-Slattery, J., O'Brien, S.J., 2000. Genomic

5 ancestry of the American puma (Puma concolor). Journal of Heredity 91, $6 \quad 186-197$.

8 Da Silva, M.N.F., Patton, J.L., 1993. Amazonian phylogeography: mtDNA 9 sequence variation in arboreal echimyid rodents (Caviomorpha).

10 Molecular Phylogenetics and Evolution 2, 243-255.

11

12 Drummond, A.J., Rambaut, A., 2007. BEAST: Bayesian evolutionary analysis

13 by sampling trees. BMC Evolutionary Biology 7, 214 doi:10.1186/1471-2148-

$14 \quad 7-214$.

15

16 Dumont, J.F., 1996. Neotectonics of the Subandes-Brazilian craton

17 boundary using geomorphological data: The Maranon and Beni basins.

18 Tectonophysics 257, 137-151.

19

20 Dupanloup, I., Schneider, S., Excoffier, L., 2002 A simulated annealing

21 approach to define the genetic structure of populations. Molecular

22 Ecology 11, 2571-2581. 
2 Duplaix, N., 1980. Observation on the ecology and behaviour of the giant

3 river otter Pteronura brasiliensis in Suriname. Terre Vie 34, 496-620.

4

5 Duplaix, N., Waldemarin, H.F., Groenedijk, J., Evangelista, E., Munis, M.,

6 Valesco, M., Botello, J.C., 2008. Pteronura brasiliensis. In: IUCN 2010. IUCN

7 Red List of Threatened Species. Version 2010.4. www.iucnredlist.org.

8 Downloaded on 10 Jan 2011.

10 Espurt, N., Baby, P., Brusset, S., Roddaz, M., Hermoza, W., Regard, V.,

11 Antoine, P-O., Salas-Gismondi, R., Bolaños, R., 2007. How does the Nazca

12 Ridge subduction influence the modern Amazonian foreland basin?

13 Geology 35, 515-518.

15 Excoffier, L., Laval, G., Schneider, S., 2005. Arlequin ver. 3.0: An integrated

16 software package for population genetics data analysis. Evolutionary

17 Bioinformatics Online 1, 47-50.

19 Ferrando, A., Ponsa, M., Marmi, J., Domingo-Roura, X., 2004. Eurasian

20 otters, Lutra lutra, have a dominant mtDNA haplotype from the Iberian

21 Peninsula to Scandinavia. Journal of Heredity 95, 430-435. 
1 Fjeldså, J., 1994. Geographical patterns for relict and young species of

2 birds in Africa and South America and implications for conservation

3 priorities. Biodiversity and Conservation 3, 207-226.

4

5 Flynn, J.J., Kowallis, B.J., Nuñez, C., Carranza-Castañeda, O., Miller, W.E.,

6 Swisher, C.C., Lindsay, E., 2005. Geochronology of Hemphillian-Blancan

7 aged strata, Guanajuato, Mexico, and implications for timing of the Great

8 American Biotic Interchange. Geology 113, 287-307.

10 Fu, Y-X., 1997. Statistical tests of neutrality against population growth,

11 hitchhiking and background selection. Genetics 147, 915-925.

13 Fulton, T.L., Strobeck, C., 2007. Novel phylogeny of the raccoon family 14 (Procyonidae: Carnivora) based on nuclear and mitochondrial DNA 15 evidence. Molecular Phylogenetics and Evolution 43, 1171-1177.

17 Garcia, D.M., Marmontel, M., Rosas, F.W., Santos, F.R., 2007. Conservation 18 genetics of the giant otter (Pteronura brasiliensis (Zimmerman, 1780))

19 (Carnivora, Mustelidae). Brazilian Journal of Biology 67, 631-637.

21 Garda, A.A., Cannatella, D.C., 2007. Phylogeny and biogeography of

22 paradoxical frogs (Anura, Hylidae, Pseudae) inferred from 125 and 165 
1 mitochondrial DNA. Molecular Phylogenetics and Evolution

2 doi:10.1016/j.ympev.2006.11.028.

3

4 Gillman, L.N., Keeling, D.J., Ross, H.A., Wright, S.D., 2009. Latitude, elevation

5 and the tempo of molecular evolution in mammals. Proceedings of the

6 Royal Society B 276, 3353-3359.

8 Gonzalez, S., Maldonado, J.E., Leonard, J.A., Vila, C., Barbanti Duarte,

9 J.M., Merino, M., Brum-Zorrilla, N., Wayne, R.K., 1998. Conservation genetics

10 of the endangered Pampas deer (Ozotoceros bezoarticus). Molecular

11 Ecology 7, 47-56.

12

13 Gottgens, J.F., Perry, J.E., Fortney, R.H., Meyer, J.E., Benedict, M., Rood,

14 B.E., 2001. The Paraguay-Parana Hidrovia: Protecting the Pantanal with

15 lessons from the past. BioScience 51, 301-308.

17 Groenendijk, J., Hajek, F. \& Schenck, C., 2004. Pteronura brasiliensis. In:

18 IUCN 2004. 2004 IUCN Red List of Threatened Species. <www.redlist.org>.

19 Downloaded on 07 November 2005.

21 Groenendijk. J., Hajek, F., Duplaix, N., Reuther, C., van Damme, P.,

22 Schenck, C., Staib, E., Wallace, R., Waldemarin, H., Notin, R., Marmontel, 
1 M., Rosas, F., Ely de Mattos, G., Evangelista, E., Utreras, V., Lasso, G.,

2 Jacques, H., Matos, K., Roopsind, I., Botello, J.C., 2005. Surveying and

3 monitoring distribution and population trends of the giant otter (Pteronura

4 brasiliensis). Guidelines for a standardisation of survey methods as

5 recommended by the giant otter section of the IUCN/SSC Otter Specialist

6 Network. Habitat 16, 1-100.

8 Groenendijk, J., Hajek, F., 2006. Giants of the Madre de Dios. Ayuda Para

9 Vida Silvestre Amenazada-Sociedad Zoologica de Francfort, Lima, Peru.

11 Guindon, S.E., Gascuel, O., 2003. A simple, fast and accurate algorithm to

12 estimate large phylogenies by maximum likelihood. Systematic Biology 52,

$13 \quad 696-704$.

15 Haffer, J., 1969. Speciation in Amazonian forest birds. Science 165, 13116137.

18 Haffer, J., 1997. Alternative models of vertebrate speciation in Amazonia:

19 an overview. Biodiversity and Conservation 6, 451-476.

21 Hailer, F., Helander, B., Folkestad, O., Ganusevich, S.A., Garstad, S., Hauff,

22 P., Koren, C., Nygård, T., Volke, V., Vilà, C., Ellegren, H., 2006. Bottlenecked 
1 but long-lived: high genetic diversity retained in white-tailed eagles upon

2 recovery from population decline. Biology Letters 2, 316-319.

4 Harris, C.J., 1968. Otters: a Study of the Recent Lutrinae. Weidenfeld and

5 Nicolson, London.

6

7 Harris, M.A., Tomas, W., Mourão, G., Da Silva, C.J., Guimarães, E., Sonoda,

8 F., Fachim, E., 2005. Safeguarding the Pantanal wetlands: threats and

9 conservation initiatives. Conservation Biology 19, 714-720.

11 Ho, S.Y.W., 2007. Calibrating molecular estimates of substitution rates and

12 divergence times in birds. Journal of Avian Biology 38, 409-414.

14 Hrbek, T., Farias, I.P., Crossa, M., Sampaio, I., Porto, J.I.R., Meyer, A., 2005.

15 Population genetic analysis of Arapaima gigas, one of the largest

16 freshwater fishes of the Amazon basin: implications for its conservation.

17 Animal Conservation 8, 297-308.

18

19 Hubert, N., Renno, J.F., 2006. Historical biogeography of South American

20 freshwater fishes. Journal of Biogeography 33, 1414-1436. 
1 Hubert, N., Duponchelle, F., Nuñez, J., Garcia-Davila, C., Paugy, D., Renno,

2 J-F., 2007. Phylogeography of the piranha genera Serrasalmus and

3 Pygocentrus: implications for the diversification of the Neotropical

4 ichthyofauna. Molecular Ecology doi: 10.1111/j.1365-294X.2007.03267.x.

5

6 Johnson, W.E., Slattery, J.P., Eizirik, E., Kim, J-H., Menotti Raymond, M.,

7 Bonacic, C., Cambre, R., Crawshaw, P., Nunes, A., Seuanez, H.N., Martins

8 Moreira, M.A., Seymour, K.L., Simon, F., Swanson, W., O'Brien, S.J. 1999.

9 Disparate phylogeographic patterns of molecular genetic variation in four

10 closely related South American small cat species. Molecular Ecology 8,

$1179-94$.

12 Kass, R.E., Raftery, A.E., 1995. Bayes factors. Journal of the American

13 Statistical Association 90,773-795.

15 Koepfli, K-P., Wayne, R.K., 1998. Phylogenetic relationships of otters

16 (Carnivora: Mustelidae) based on mitochondrial cytochrome b

17 sequences. Journal of Zoology, London 246, 401-416.

18

19 Koepfli, K-P., Deere, K.A., Slater, G.J., Begg, C., Begg, K., Grassman, L.,

20 Lucherini, M., Veron, G., Wayne, R.K., 2008. A multigene phylogeny of the

21 Mustelidae: Resolving relationships, tempo and biogeographic history of a 
1 mammalian adaptive radiation. BMC Biology 6, doi:10.1186/1741-7007-6-

210.

3

4 Koepfli, K-P., Gompper, M.E., Eizirik, E., Ho, C-C., Linden, L., Maldonado,

5 J.E., Wayne, R.K. 2007. Phylogeny of the Procyonidae (Mammalia:

6 Carnivora): Molecules, morphology and the Great American Interchange.

7 Molecular Phylogenetics and Evolution 43, 1076-1095.

8

9 Larson, S., Jameson, R., Etnier, M., Fleming, M., Bentzen, P., 2002. Loss of

10 genetic diversity in sea otters (Enhydra lutris) associated with the fur trade

11 of the 18th and 19th centuries. Molecular Ecology 11, 1899-1903.

13 Latrubesse, E.M., Rancy, A., 2000. Neotectonic influence on tropical rivers

14 of southwestern Amazon during the late quaternary: the Moa and Ipixuna

15 river basins, Brazil, Quaternary International 72, 67-72.

17 Lebarbenchon, C., Poitevin, F., Arnal, V., Montgelard, C., 2010.

18 Phylogeography of the weasel (Mustela nivalis) in the western-Palaearctic

19 region: combined effects of glacial events and human movements.

20 Heredity 105, 449-462. 
2 Leroy, S., Dupont, L., 1994. Development of vegetation and continental

3 aridity in northwestern Africa during the Late Pliocene: the pollen record

4 of ODP Site 658. Palaeogeography, Palaeoclimatology, Palaeoecology

$5 \quad 109,295-316$.

6

7 Lessa, E.P., Cook, J.A., Patton, J.L., 2003. Genetic footprints of

8 demographic expansion in North America, but not Amazonia, during the

9 Late Quaternary. Proceedings of the National Academy of Sciences 100,

$10 \quad 10331-10334$.

11

12 Librado, P., Rozas, J., 2009. DnaSP v5: A software for comprehensive

13 analysis of DNA polymorphism data. Bioinformatics 25, 1451-1452.

15 Limarino, C.O., Spalletti, L.A., 2006. Paleogeography of the upper

16 Paleozoic basins of southern South America: An overview. Journal of South

17 American Earth Science 22, 134-155.

18

19 Lindsay, E.H., Opdyke, N.D., Johnson, N.M., 1984. Blancan-Hemphilian land

20 mammal ages and late Cenozoic mammal dispersal events. Annual

21 Review of Earth and Planetary Sciences 12, 445-488. 
1 Lovejoy, N.R., De Araujo, L.G., 2000. Molecular systematics, biogeography

2 and population structure of Neotropical freshwater needlefishes of the

3 genus Potamorrhaphis. Molecular Ecology 9, 259-268.

4

5 Lundberg, J.G., Marshall, L.G., Guerrero, J., Horton, B., Malabarba,

6 M.C.S.L., Wesselingh, F., 1998. The Stage for Neotropical Fish Diversification:

7 A history of Tropical South American Rivers. In: Malabarba, L.R., Reis, R.E.,

8 Vari, R.P., Lucena, Z.M.S., Lucena, C.A.S., (Eds.) Phylogeny and

9 Classification of Neotropical Fishes. Part 1- Fossils and Geological

10 Evidence. Edipucrs, Porto Alegre, Brasil.

11

12 Marlow, J.R., Lange, C.B., Wefer, G., Rosell-Melé, A., 2000. Upwelling

13 intensification as a part of the Pliocene-Pleistocene climate transition.

14 Science 290, 2288-2291.

15

16 Marmi, J., López-Giráldez, F., Macdonald, D.W., Calafell, F.,

17 Zholnerovskaya, E., Domingo-Roura, X., 2006. Mitochondrial DNA reveals a

18 strong phylogeographic structure in the badger across Eurasia. Molecular

19 Ecology 15, 1007-1020. 
1 Molnar, P., Cane, M.A., 2002. El Niño's tropical climate and

2 teleconnections as a blueprint for pre-lce-Age climates.

3 Paleoceanography $17,1-11$.

4

5 Montoya-Burgos, J.I., 2003. Historical biogeography of the catfish genus

6 Hypostomus (Siluriformes: Loricariidae), with implications on the

7 diversification of Neotropical ichthyofauna. Molecular Ecology 12, 1855-

$8 \quad 1867$.

10 Moritz, C., 2002. Strategies to protect biological diversity and the

11 evolutionary processes that sustain it. Systematic Biology 51, 238-254.

13 Mucci, N., Pertoldi, C.. Madsen, A.B., Loeschcke, V., Randi, E., 1999.

14 Extremely low mitochondrial DNA control-region sequence variation in the

15 otter (Lutra lutra) population of Denmark. Hereditas 130, 331-336.

17 Nores, M., 1999. An alternative hypothesis for the origin of Amazonian bird

18 diversity. Journal of Biogeography 26, 475-485.

19

20 Pearse, D.E., Arndt, A.D., Valenzuela, N., Miller, B.A., Cantarelli, V., Sites,

21 J.W. Jr., 2006. Estimating population structure under nonequilibrium

22 conditions in a conservation context: continent-wide population genetics 
1 of the giant Amazon river turtle, Podocnemis expansa (Chelonia;

2 Podocnemididae). Molecular Ecology 15, 985-1006.

3

4 Posada, D., Crandall, K.A., 1998. Modeltest: testing the model of DNA

5 substitution. Bioinformatics 14, 817-818.

6

7 Prevosti, F.J., Ferrero, B., 2008. A Pleistocene giant river otter from

8 Argentina: Remarks on the fossil record and phylogenetic analysis.

9 Vertebrate Paleontology 28, 1171-1181.

10

11 Räsänen, M.E., Linna, A.M., Santos, J.C.R., Negri, F.R., 1995. Late Miocene

12 tidal deposits in the Amazonian foreland basin. Science 269, 386-390.

14 Rauch, E.M., Bar-Yann, Y., 2004. Theory predicts the uneven distribution of

15 genetic diversity within species. Nature 431, 449-452.

17 Rebesco, M.A., Camerlenghi, A., 2008. Late Pliocene margin development

18 and mega debris flow deposits on the Antarctic continental margins:

19 Evidence of the onset of the

20 modern Antarctic Ice Sheet? Palaeogeography, Palaeoclimatology,

21 Palaeoecology 260, 149-167. 
1 Regard, V., Lagnous, R., Espurt, N., Darrozes, J., Baby, P., Roddaz, M.,

2 Calderon, Y., Hermoza, W., 2009. Geomorphic evidence for recent uplift

3 of the Fitzcarrald Arch (Peru): A response to the Nazca Ridge subduction.

4 Geomorphology 107, 107-117.

5

6 Renno, J.F., Hubert, N., Torrico, J.P., Duponchelle, F., Nunez Rodriguez, J.,

7 Garcia Davila, C., Willis, S.C., Desmarais, E., 2006. Phylogeography of

8 Cichla (Cichlidae) in the upper Madeira basin (Bolivian Amazon).

9 Molecular Phylogenetics and Evolution 41, 503-510.

10

11 Roddaz, M., Brusset, S., Baby, P., Herail, G., 2006. Miocene tidal-influenced

12 sedimentation to continental Pliocene sedimentation in the forebulge-

13 backbulge depozones of the Beni-Mamore foreland Basin (northern

14 Bolivia). Journal of South American Earth Sciences 20, 351-368.

16 Roddaz, M., Hermoza, W., Mora, A., Baby, P., Parra, M., Christophoul, F.,

17 Brusset, S., Espurt, N., 2010. Cenozoic sedimentary evolution of the

18 Amazonian foreland basin system. In: Hoorn C and Wesselingh F (Eds.)

19 Amazonia, Landscape and Species Evolution: a look at the Past. Wiley-

20 Blackwell, Oxford, pp 61-88. 
1 Rogers, A.R., 1995. Genetic evidence for a Pleistocene population

2 explosion. Evolution 49, 608-615.

3

4 Rogers, A.R., Harpending, H., 1992. Population growth curves in the

5 distribution of pairwise genetic differences. Molecular and Biological

6 Evolution 9, 552-569.

8 Rohland, N., Hofreiter, M., 2007. Ancient DNA extraction from bones and

9 teeth. Nature Protocols 2, 1756-1762.

11 Ronquist, F., Huelsenbeck, J.P., 2003. MrBayes 3: Bayesian phylogenetic

12 inference under mixed models. Bioinformatics 19, 1572-1574.

14 Rossetti, D.F., de Toledo, P.M., Goes, A.M., 2005. New geological

15 framework for Western Amazonia (Brazil) and implications for

16 biogeography and evolution. Quaternary Research 63, 78-89.

18 Sivasundar, A., Bermingham, E., Orti, G., 2001. Population structure and

19 biogeography of migratory freshwater fishes (Prochilodus: Characiformes)

20 in major South American rivers. Molecular Ecology 10, 407-417. 
1 Sloan, A., Crowley, T.J., Pollard, D., 1996. Modeling of Middle Pliocene

2 climate with the NCAR GENESIS general circulation model. Marine

3 Micropaleontology 27, 51-61.

4

5 Swofford, D.L., 2002. PAUP*. Phylogenetic Analysis Using Parsimony (*and

6 Other Methods). Version 4. Sinaver Associates, Sunderland, Massachusetts.

8 Tchaicka, L., Eizirik, E., De Oliveira, T.G., Candido, J.F., Freitas, T.R.O., 2007.

9 Phylogeography and population history of the crab-eating fox

10 (Cerdocyon thous). Molecular Ecology 16, 819-838.

11

12 Toivonen, T., Mäki, S., Kalliola, R., 2007. The riverscape of Amazonia- a

13 quantitative approach to the fluvial biogeography of the region. Journal

14 of Biogeography 34, 1374-1387.

15

16 Tomas, W.M., Lima Borges, P.A., Rocha, H.J.F., Sa Filho, R., Kutchenski, F.

17 Jnr., Villafaine Udry, T., 2000. Potencial dos rios Aquidauana e Miranda, no

18 Pantanal de Mato Grosso do Sul, para a conservação da ariranha

19 (Pteronura brasiliensis). Anais do III Simpósio sobre recursos naturais e

20 sócio-econômicos do Pantanal. Empresa Brasileira de Pesquisa

21 Agropecuaria (Embrapa). Pantanal, Corumbá, Brasil. 
1 Torrico, J.P., Hubert, N., Desmarais, E., Duponchelle, F., Nuñez Rodriguez,

2 J., Montoya-Burgos, J., Garcia Davila, C., Carvajal-Vallejos, F.M., Grajales,

3 A.A., Bonhomme, F., Renno, J-F., 2009. Molecular phylogeny of the genus

4 Pseudoplatystoma (Bleeker, 1862): Biogeographic and evolutionary

5 implications. Molecular Phylogenetics and Evolution 51, 588-594.

7 Trinca, C.S., Waldemarin, H.F., Eizirik, E., 2007. Genetic diversity of the

8 Neotropical otter (Lontra longicaudis Olfers, 1818) in Southern and

9 Southeastern Brazil. Brazilian Journal of Biology 67, 813-818.

11 Van der Hammen, T., 1975. The Pleistocene changes of vegetation and

12 climate in tropical South America. Journal of Biogeography 1, 3-26.

14 Vilà, C., Amorim, I.R., Leonard, J.A., Posada, D., Castroviejo, F., Petrucci-

15 Fonseca, F., Crandall, K.A., Ellegren, H., Wayne, R.K., 1999. Mitochondrial

16 DNA phylogeography and population history of the grey wolf Canis lupus.

17 Molecular Ecology 8, 2089-2103.

19 Vizcaıno, S.F., Farina, R.A., Zarate, M.A., Bargo, M.S., Schultz, P., 2004.

20 Palaeoecological implications of the Mid-Pliocene faunal turnover in the

21 Pampean Region (Argentina). Palaeogeography, Palaeoclimatology,

22 Palaeoecology $213,101-113$. 
2 Weir, J.T., Schluter, D., 2007. The latitudinal gradient in recent speciation

3 and extinction rates of birds and mammals. Science 315, 1574- 1576.

4

5 Wesselingh, F.P., Salo, J.A., 2006. Miocene perspective on the evolution of

6 the Amazonian biota. Scripta Geologica 133, 439-458.

8 Whitehead, J.M., McMinn, A., 2002. Kerguelen PlateaU Quaternary-late

9 Pliocene palaeoenvironments: from diatom, silicoflagellate and 10 sedimentological data. Palaeogeography, Palaeoclimatology,

11 Palaeoecology 186, 335-368.

13 Wilkinson, M.J., Marshall, L.G., Lundberg, J.G., 2006. River behavior on 14 megafans and potential influences on diversification and distribution of 15 aquatic organisms. Journal of South American Earth Sciences 21, 151-172.

17 Willemsen, G.F., 1992. A revision of the Pliocene and Quaternary Lutrinae 18 from Europe. Scripta Geologica 101, 1-115.

20 Whitmore, T.C., Prance, G.T., 1987. Biogeography and Quaternary history

21 in South America. Oxford University Press, Oxford. 
1 Zambrana Rojas, V.D., 2007. Distribucion y estado poblacional de la

2 Iondra (Pteronura brasiliensis) en los rios Blanco y San Martin (Cuenca del

3 Rio Iténez). Undergraduate thesis, University of San Simon, Cochabamba,

4 Bolivia

5

6

7 Figure Legends.

8

9 Fig. 1 The drainage system of South America and the geographic origin of

10 samples used in this study. Watersheds are outlined by dashed lines and

11 the positions of important geological arches are indicated. Black circles

12 refer to sequences from this study, grey circles to sequences from Garcia

13 et al. (2007).

15 Fig. 2 Statistical parsimony haplotype network based on concatenated

16 cytochrome b and control region sequence data. Nodes are colored to

17 reflect clustered phylogroups, with sub-clusters within each phylogroup

18 identified. Node size corresponds to haplotype frequency. Grey nodes

19 represent inferred mutational steps between haplotypes.

21 Fig. 3 Phylogenetic relationships reconstructed using Bayesian and

22 maximum likelihood methods of concatenated cytochrome $b$ and 
1 control region dataset. Bootstrap support values greater than 40 and

2 Bayesian posterior probability values greater than 0.50 are shown for

3 phylogroup-level splits. The geographic origin for each of the taxa (coded

$4 \quad 1.01-8.08)$ is given in Appendix A.

5

6 Fig. 4 Divergence times of phylogroups as resolved in BEAST. Node bars

7 display the $95 \%$ HPD. Time in the axis is given in millions of years before

8 present. Phylogroups resolved by SAMOVA are highlighted.

10 Fig. 5 Mismatch distribution of pairwise nucleotide differences among

11 individuals within the four phylogroups. Histograms represent the observed

12 differences, while lines represent the expected distribution.

14 Fig. 6 Important regions of genetic diversity within the giant otter

15 correlated with Pleistocene rainforest refugia in grey identified by

16 Whitmore and Prance (1987) based on data gathered from birds,

17 butterflies, and plants and accounting for soil and precipitation. The

18 geographic extent of the four phylogroups are highlighted and the

19 historical extent of the species' range is also shown. 


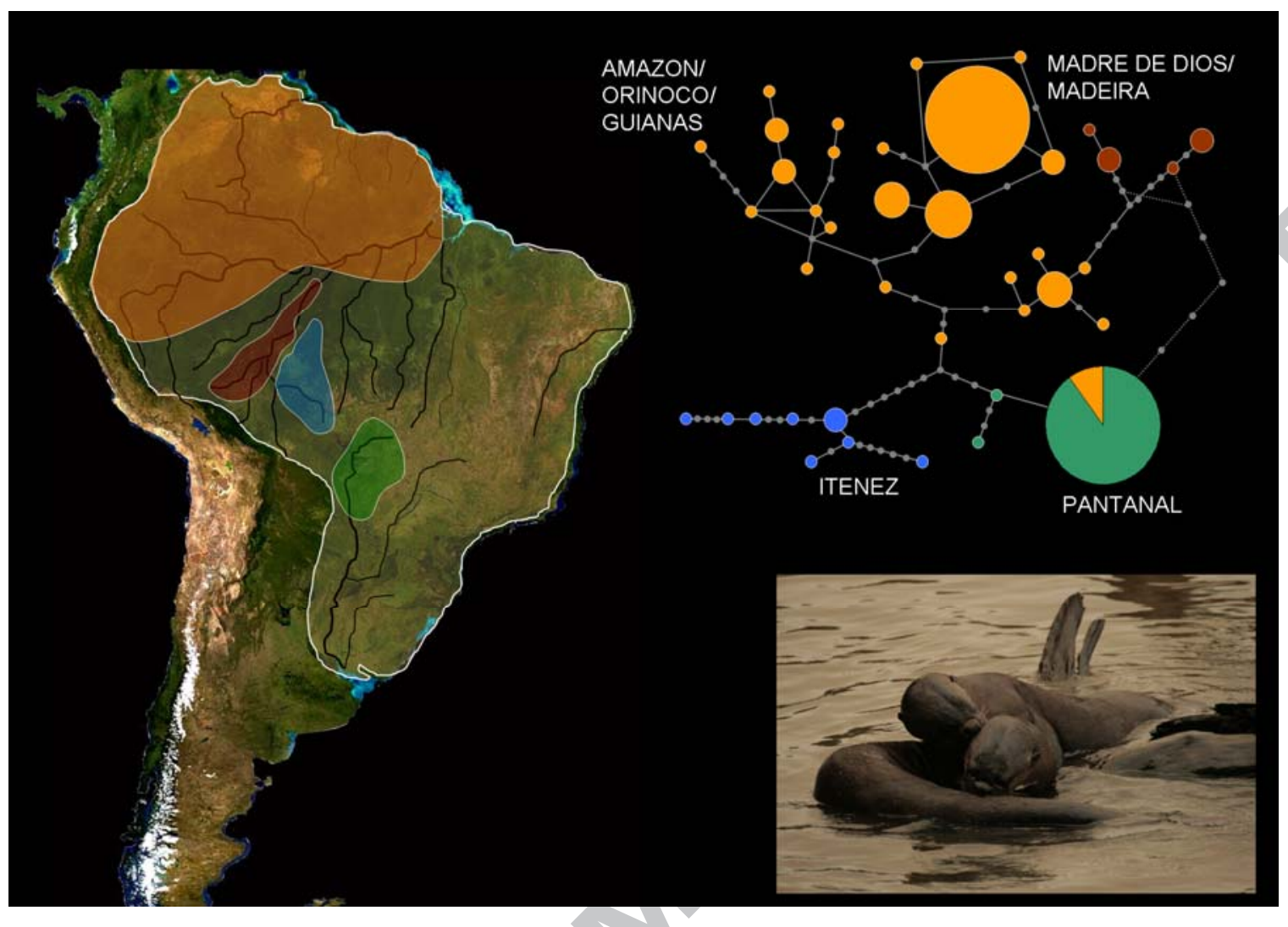


1 Highlights of MPE-10-312R 1

2 Evolutionary history and identification of Conservation Units in the giant

3 otter, Pteronura brasiliensis

4

$5 \quad>$ In this paper we investigate the phylogeography of the endangered

6 giant otter.

7 >We sequence mitochondrial control region and cytochrome b genes.

$8>$ We resolve four distinct phylogroups, constituting conservation units.

9 >We tested three hypotheses of Amazonian diversification.

10 >The Plio-Pleistocene origin of the phylogroups appears driven by

11 changes in climate and drainage.

12

13 


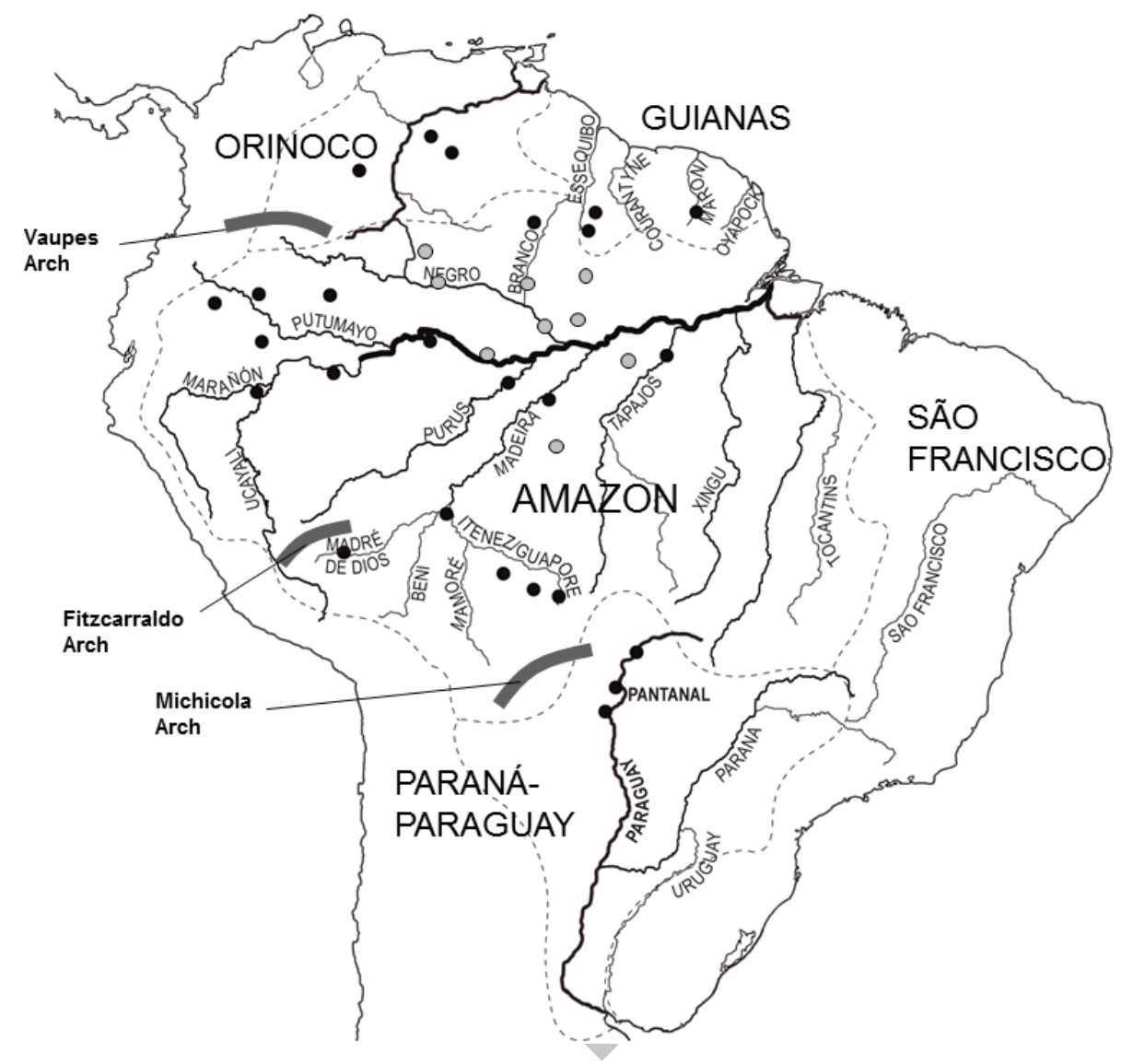




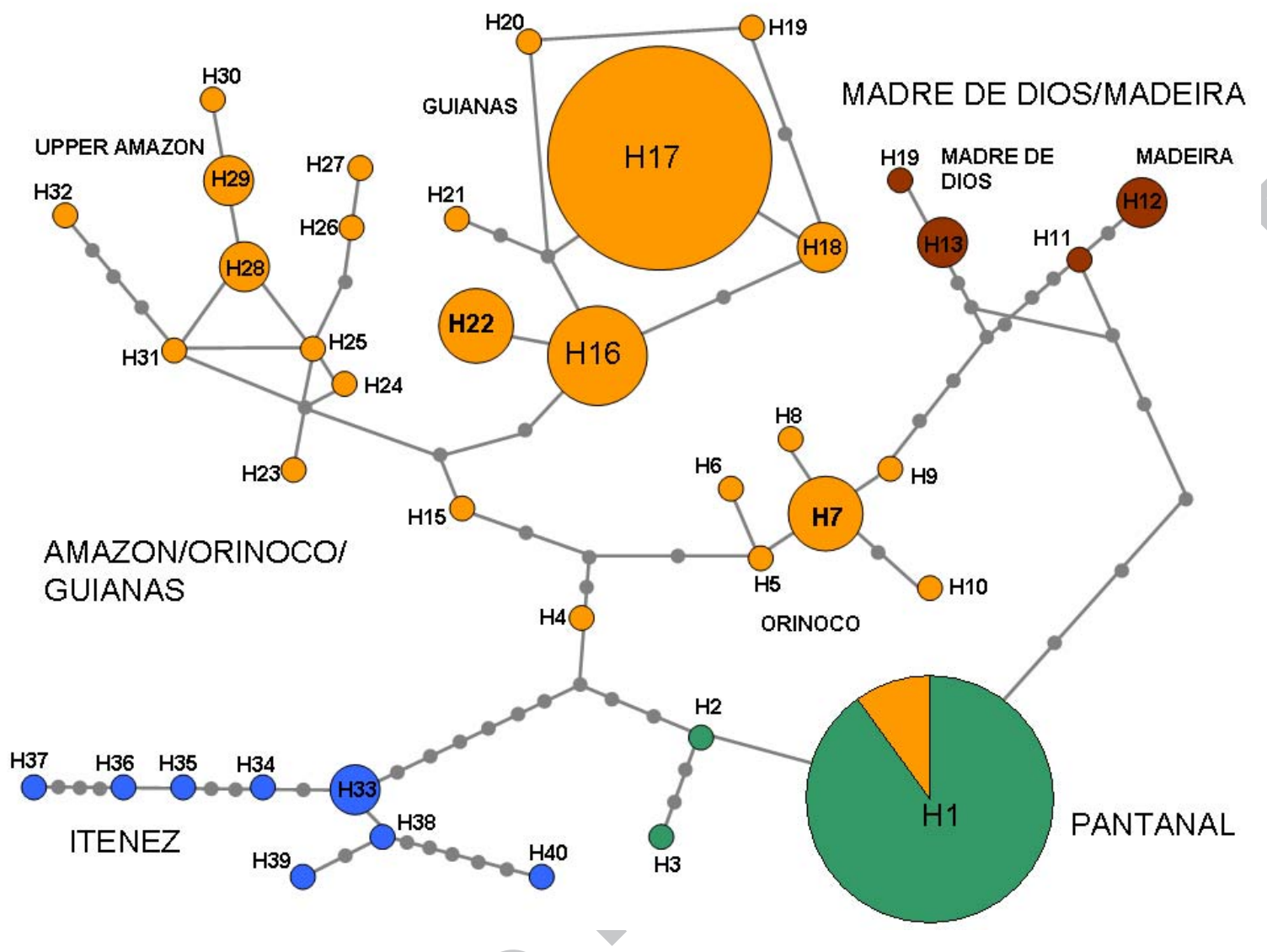



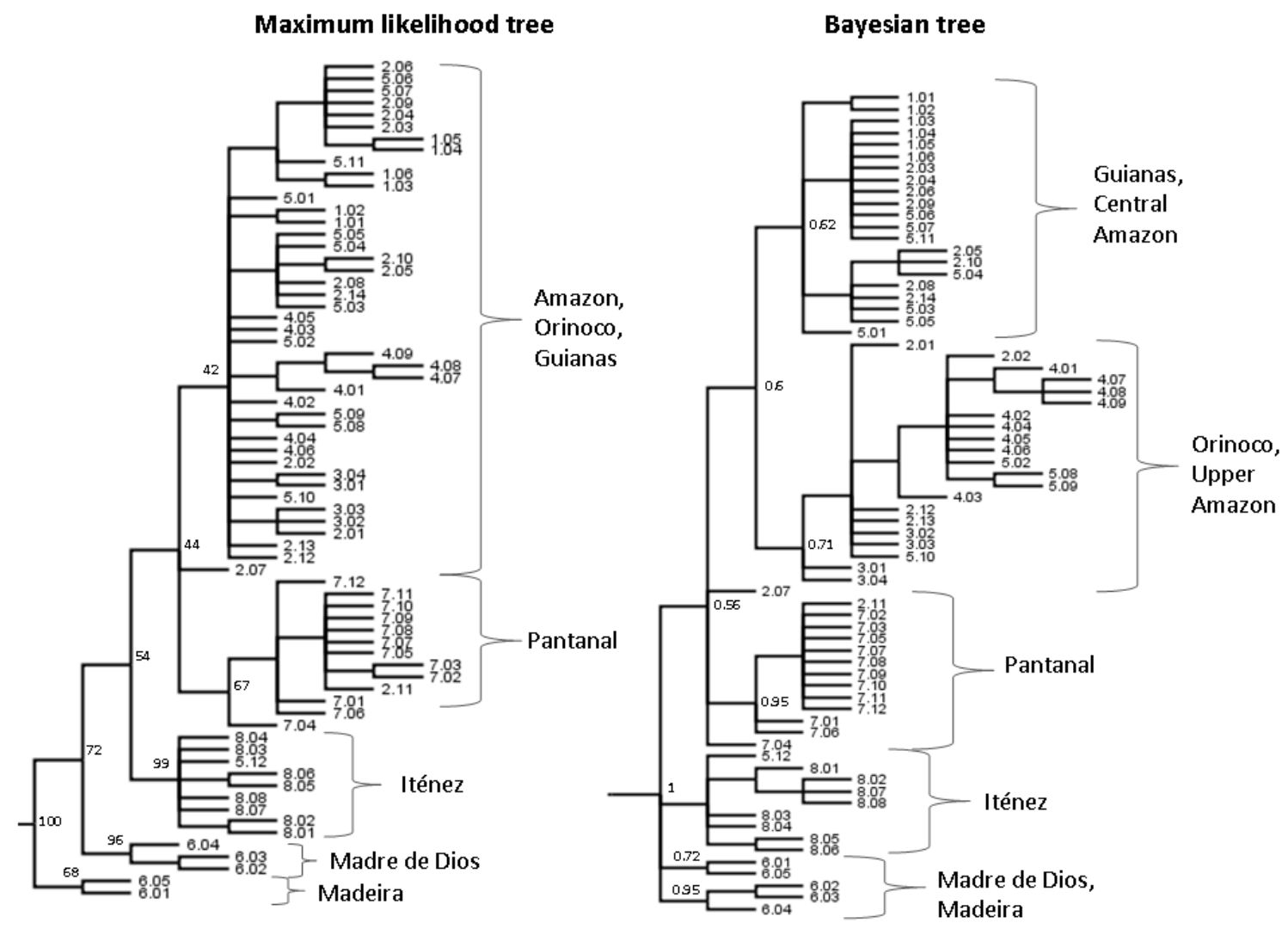


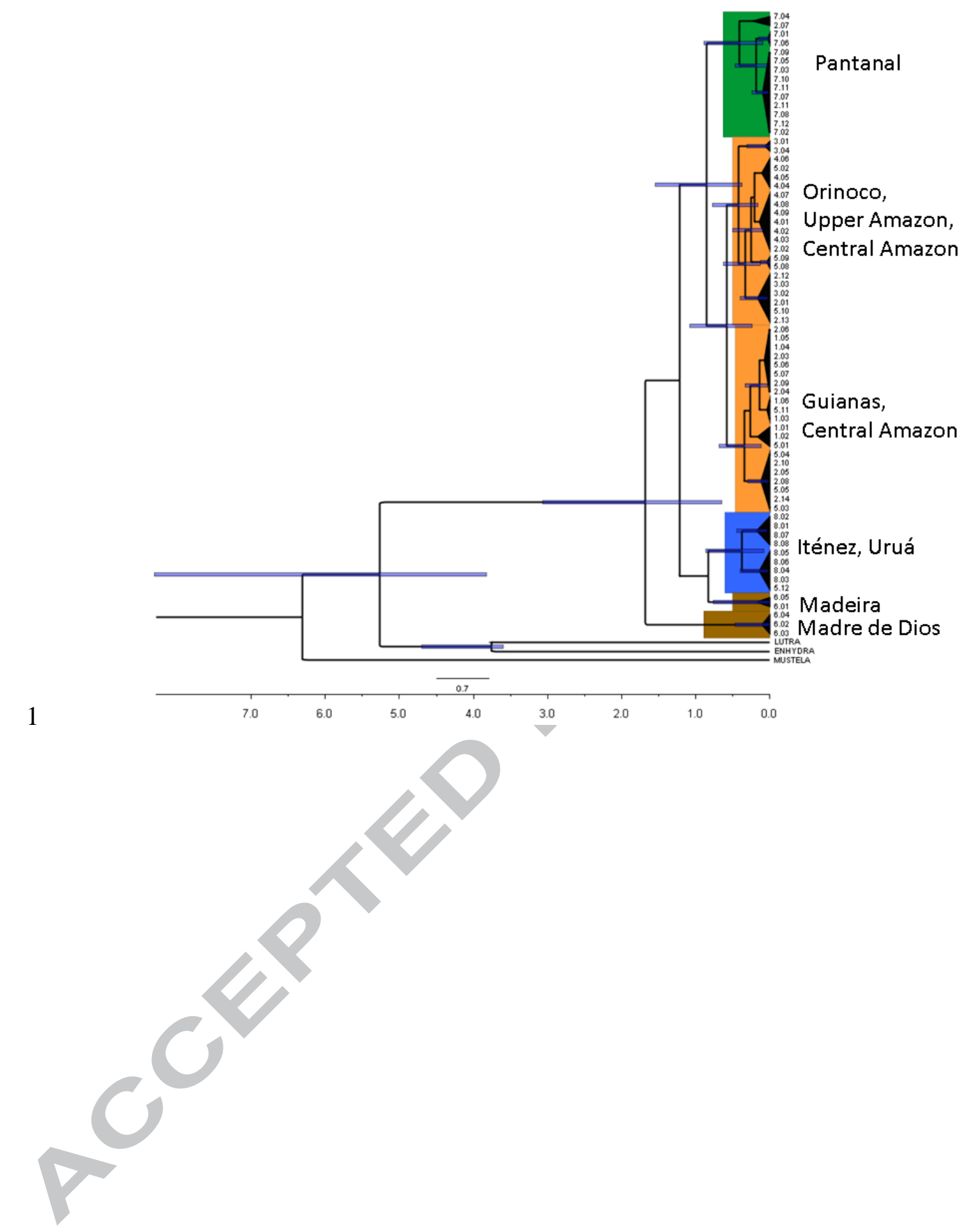



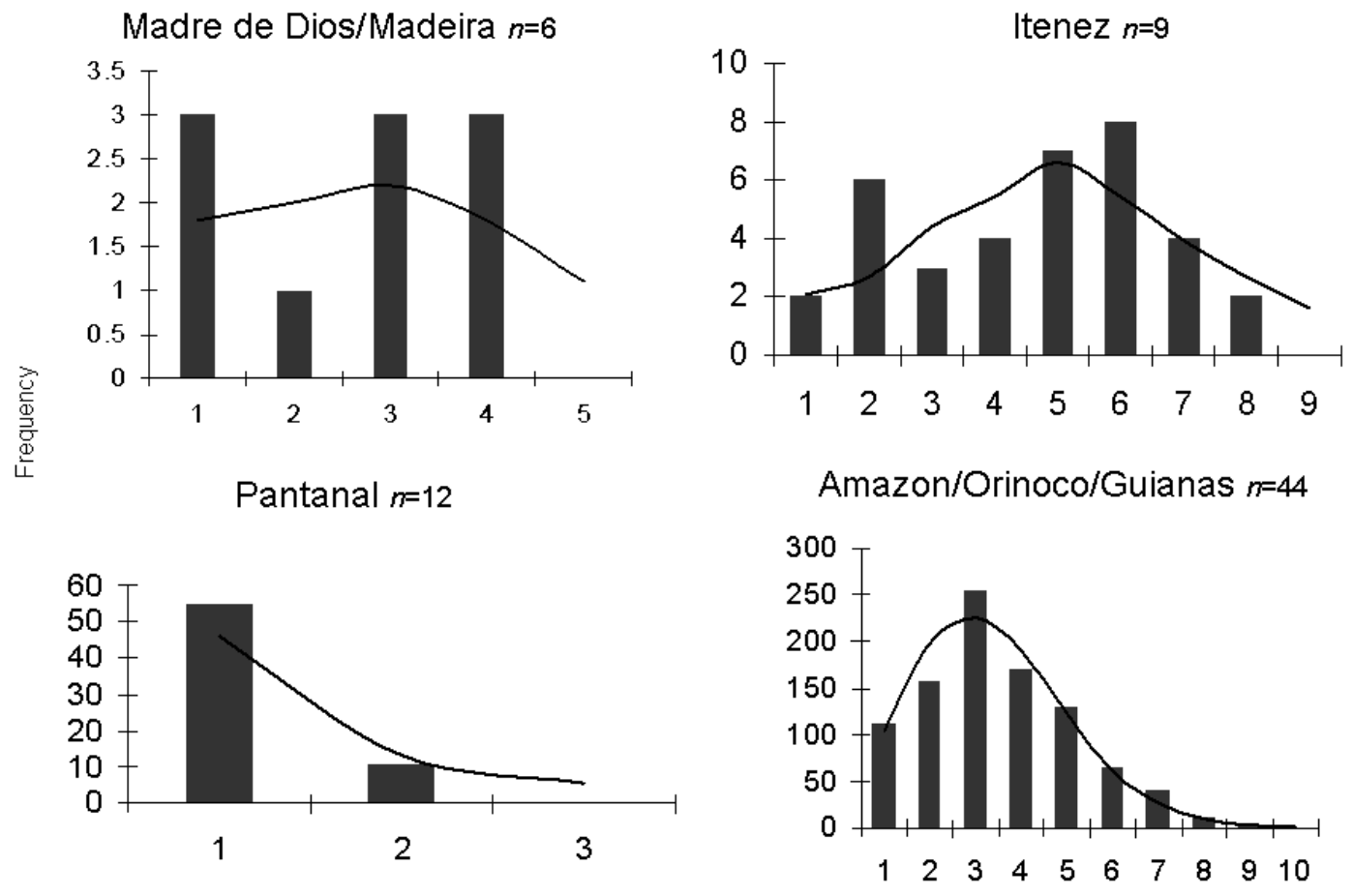

Number of pairwise differences 


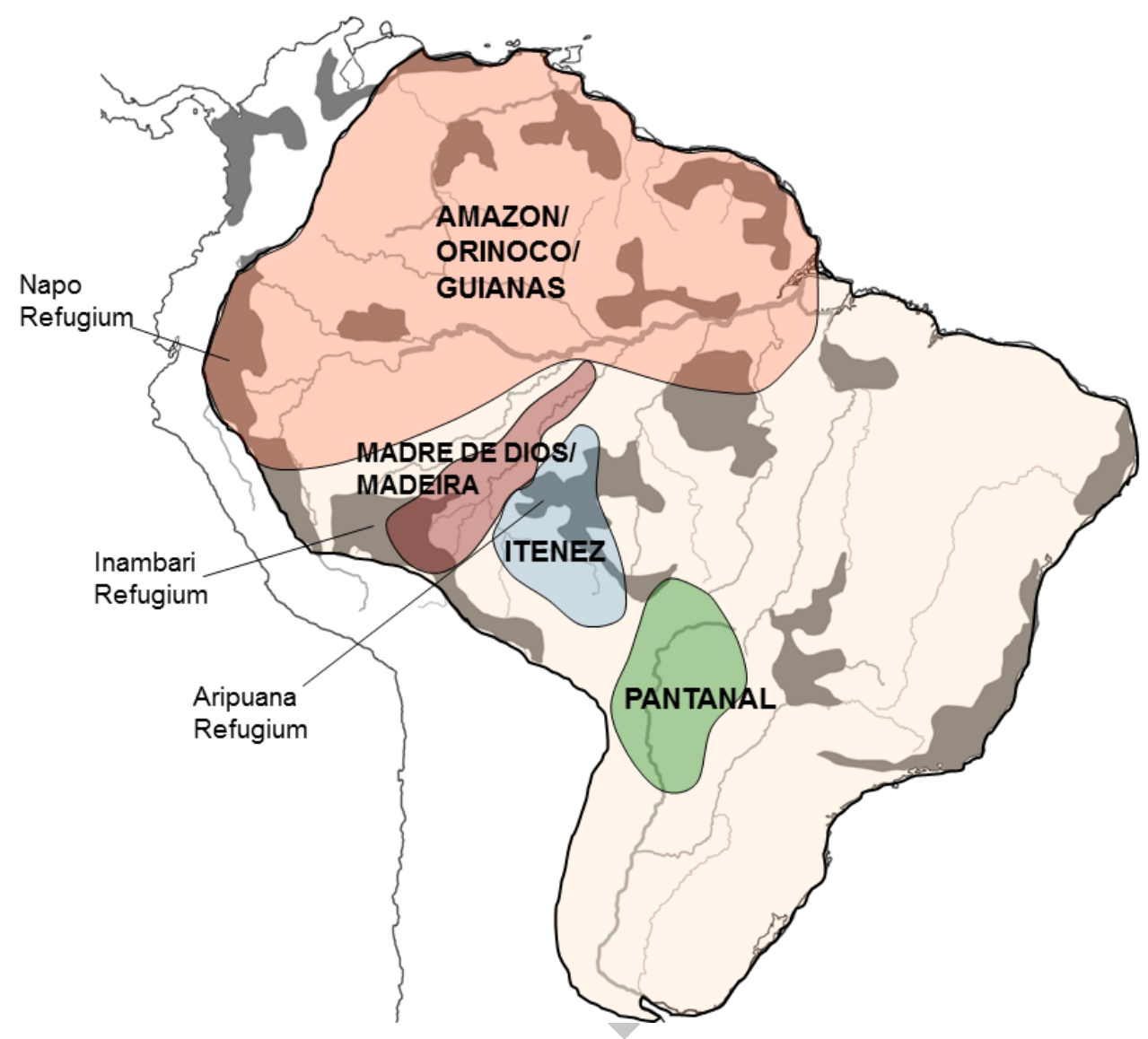




\section{Tables}

3 Table 1 Three hypothesized drivers of diversification in Amazonia and the

4 predictions they make regarding the phylogeographical structure of the

5 giant otter.

6

\begin{tabular}{|c|c|}
\hline $\begin{array}{l}\text { Palaeoecological } \\
\text { drivers of } \\
\text { divergence }\end{array}$ & References \\
\hline
\end{tabular}

Sister lineages will be found either side of a Palaeogeography Da Silva and Patton 1998; geological arch. Divergence dates will be Hubert et al. 2007 pre-Pliocene except in the case of the Fitzcarrald Arch, a more recent formation.

Populations in adjacent drainage basins will

Lundberg et al. 1998;

Hydrogeology Montoya-Burgos 2003; Hubert and Renno 2006

Haffer 1969; Whitmore and

Pleistocene glacial Prance 1987; Marquez et al. refugia
2006; Conn and Mirabello

2007; Mucci et al. 2010 exhibit a pattern of ancestry directly across the watersheds, with samples from one drainage clustering within the larger clade of its neighbor.

Discrete regions of genetic diversity will be seen, not necessarily correlated with geological features or altitude. The phylogeographical pattern may agree with that of rainforest refugia identified by Whitmore and Prance (1987). For the last glaciation to have been a driver, divergence times between phylogroups will be $<80,000$ BP

Table 2 Genetic distance among phylogroups $\left(F_{S T}\right)$

11

\begin{tabular}{ccccc}
\hline & Iténez & $\begin{array}{c}\text { Madre de } \\
\text { Dios/Madeira }\end{array}$ & Pantanal & Amazon/Orinoco/Guianas \\
\hline Iténez & & & \\
Madre de Dios/Madeira & 0.64 & & \\
Pantanal & 0.70 & 0.74 & \\
Amazon/Orinoco/Guianas & 0.69 & 0.63 & 0.73 \\
\hline
\end{tabular}

12

13

14 
3 Table 3 Genetic diversity of each phylogroup identified by SAMOVA

4

\begin{tabular}{lcccccc}
\hline \multicolumn{1}{c}{ Phylogroup } & $\begin{array}{c}\text { Number } \\
\text { of } \\
\text { samples }\end{array}$ & $\begin{array}{c}\text { Number of } \\
\text { Sampling } \\
\text { sites }\end{array}$ & $\begin{array}{c}\text { Number of } \\
\text { haplotypes }\end{array}$ & $\begin{array}{c}\text { Haplotype } \\
\text { diversity }(h)\end{array}$ & $\begin{array}{c}\text { Number of } \\
\text { polymorphic } \\
\text { sites }\end{array}$ & $\begin{array}{c}\text { Nucleotide } \\
\text { diversity per } \\
\text { site }(\pi)\end{array}$ \\
\hline Iténez & 9 & 4 & 8 & 0.97 & 12 & 0.0073 \\
Madre de Dios/Madeira & 6 & 3 & 6 & 0.93 & 7 & 0.0076 \\
Pantanal & 12 & 4 & 3 & 0.44 & 2 & 0.0015 \\
Amazon/Orinoco/Guianas & 44 & 23 & 17 & 0.88 & 18 & 0.0067 \\
\hline
\end{tabular}

5

6 


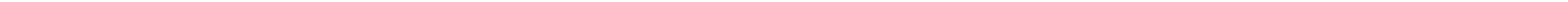

